\title{
LIDIA YAMAMOTO
}

Desenvolvimento de uma multiplex-nested-PCR para a detecção simultânea de sete patógenos com DNA no genoma em casos suspeitos de infecção congênita.

Tese apresentada ao Programa de Pós-Graduação em Medicina Tropical e Saúde Internacional da Universidade de São Paulo para obtenção do título de doutorado.

Área de Concentração: Medicina Tropical e Saúde Internacional Orientadora: Profa. Dra. Thelma Suely Okay

São Paulo

2016 
Ficha catalográfica

Preparada pela Biblioteca do Instituto de Medicina Tropical de São Paulo da

Universidade de São Paulo

(C) Reprodução autorizada pelo autor

Yamamoto, Lidia

Desenvolvimento de uma multiplex-nested-PCR para a detecção simultânea de sete patógenos com DNA no genoma em casos suspeitos de infecção congênita / Lidia Yamamoto. - São Paulo, 2016.

Tese (Doutorado) - Instituto de Medicina Tropical de São Paulo da Universidade de São Paulo, para obtenção do título de Doutor em Ciências. Área de concentração: Doenças Tropicais e Saúde Internacional Orientadora: Thelma Suely Okay

Descritores: 1. REAÇÃO EM CADEIA POR POLIMERASE. 2. DOENÇAS INFECCIOSAS. 3. GESTANTES. 4. LÍQUIDO AMNIÓTICO. 5. SEQUENCIAMENTO GENÉTICO.

USP/IMTSP/BIB-19/2016. 
Dedico este trabalho aos meus pais Isao e Kioko,

sobretudo in memoriam a minha irmã Clarice

Perseverância e Namaste _ $\_$ 


\section{AGRADECIMENTOS}

À Deus pela força e fé;

À minha orientadora Profa. Dra. Thelma Suely Okay, por ter me dado essa oportunidade em realizar o doutorado e me orientado com tanto dedicação. E pela confiança depositada em minha pessoa;

À minha irmã Cacilda Yamamoto Spinelli e minha sobrinha Samira Yamamoto Penna por todo amor e alegria;

À pesquisadora Dra. Kelly Aparecida Kanunfre, por todo apoio científico e técnico durante a elaboração da tese;

Aos professores pesquisadores do Laboratório de Soroepidemiologia e Imunobiologia do Instituto de Medicina Tropical da USP Profa. Dra. Hiro Goto, Prof. Dr. Angelo Lauletta Lindoso e Prof. Dr. Paulo César Cotrim;

Às pesquisadoras e técnicas do Laboratório de Soroepidemiologia e Imunobiologia do Instituto de Medicina Tropical da USP:, Guita Rubinsky Elefant,.Maria Carmem A. Sanchez, Edite Hatsumi Yamashiro Kanashiro, Beatriz Celeste, Sandra Regina, Christiane Yumi Ozaki, Elizabete Ourique e Mussya Rocha pela assessoria e amizade;

Aos meus colegas de laboratório Jonatas Cristian Rodrigues, Júlio César Ferreira Rente Filho, Lília Spaleta Targa, Leandro Emidio Teixeira, Marcos Luiz Alves Andrino, Paulo Tadashi Shimokawa Wilson Domingues, pelo bom convívio ao longo destes anos e pelos trabalhos que realizamos juntos;

Aos alunos do Laboratório de Soroepidemiologia e Imunobiologia do Instituto de Medicina Tropical da USP :Alline Rodrigues, Arianne Leal, Luiza Reis, Eduardo Sanchez, Mahyumi Fujimori, Mariane Brito, Camila Sato, Marina Souza, Renata Silva, Daiane Dias e Orlando Sevillano pelos dias de convivência;

Ao Dr. Antonio Gomes Amorim Neto, Dra. Joelma Andrade Queiroz, aos residentes e enfermeiros do ambulatório da Obstetrícia do Hospital das Clínicas da FMUSP de São Paulo, pela realização das amniocenteses e cordocenteses das gestantes deste trabalho; 
Aos médicos e enfermeiros do Hospital Vila Nova Cachoerinha - São Paulo, pela realização das coletas de materiais biológicos deste trabalho;

Às gestantes do ambulatório da Obstetrícia do Hospital das Clínicas da FMUSP de São Paulo e do Hospital Vila Nova Cachoeirinha - São Paulo, por terem consentido o uso dos materiais biológicos para a realização deste trabalho;

À pesquisadora Dra. Gilda Maria Barbaro del Negro e toda a sua equipe do Laboratório de Micologia do Instituto de Medicina Tropical da USP-SP por ter cedido o uso do espaço físico e reagentes para a realização de algumas etapas do projeto;

À secretária Eliane Fernandes da seção de Pós-Graduação do Instituto de Medicina Tropical da USP-SP por toda ajuda recebida ao longo do meu doutorado;

A todos os funcionários do Instituto de Medicina Tropical da USP-SP, por todo suporte necessário para realização deste trabalho. 


\section{RESUMO}

Yamamoto L. Desenvolvimento de uma multiplex-nested-PCR para a detecção simultânea de sete patógenos com DNA no genoma em casos suspeitos de infecção congênita. [tese]. São Paulo: Instituto de Medicina Tropical de São Paulo da Universidade de São Paulo; 2016.

No Brasil, houve significativa redução da mortalidade infantil, porém não do componente perinatal que corresponde a $13 \%$ do total. O diagnóstico das infecções congênitas com base apenas em dados clínicos, ultrassonográficos e sorológicos maternos é muito difícil, havendo necessidade de um número grande de sorologias, algumas delas não disponíveis na rotina laboratorial, e o simples encontro de sorologia positiva (IgM e IgG positivas) na gestante não constitui prova inequívoca da transmissão vertical. A extração de DNA/RNA a partir de líquido amniótico possui baixo rendimento, dificultando a realização de inúmeros testes moleculares. Sendo assim, na tentativa de preencher esta lacuna diagnóstica, a presente pesquisa teve como objetivo a padronização e validação de uma multiplex-nested-PCR capaz de detectar, de forma simultânea, sete patógenos que causam infecções congênitas e possuem DNA no genoma: CMV, HSV, VZV, EBV, adenovírus, parvovírus B19 e Toxoplasma gondii, com determinação da frequência relativa de cada microrganismo em um grupo de gestantes com (estudo) e sem suspeita de infecção (controle). No grupo de estudo, 147 gestantes foram recrutadas, com 57 casos positivos (38,8\%): 32 com $T$. gondii (21,8\% do total e 56,1\% dos positivos); 12 com CMV $(8,1 \%$ e $21 \%) ; 5$ casos com parvovírus (3,4\% e 8,8\%); 4 com adenovírus (2,7\% e $7 \%$ ) e 4 casos com dupla detecção ( 2 casos com $T$. gondii e CMV; 1 caso com $T$. gondii e VZV e 1 caso com CMV e parvovírus B19). O grupo controle contou com 193 casos e 197 amostras: líquido amniótico para cariotipagem em gestantes com idade avançada $(n=44)$; amostras de sangue $(n=150)$, e fragmentos de placentas $(n=3)$ de gestantes com pré-natal normal, no momento do parto. Neste grupo, duas amostras de líquido amniótico foram positivas ( $1,04 \%$ do total de casos e 4,5\% dos líquidos): um caso de adenovírus em feto com cariótipo normal, e um caso de $T$. gondii em feto com translucência nucal aumentada e trissomia do 21 (síndrome de Down). Neste grupo controle 13/193 cariótipos fetais se encontravam alterados $(6,7 \%)$. A falta de estudos similares dificultou a comparação dos resultados, porém a multiplex-nested-PCR detectou número quase seis vezes superior ao detectado pelos exames disponíveis nos centros participantes. Todos os resultados positivos foram confirmados pelo sequenciamento dos produtos de amplificação. A similaridade entre as sequências amplificadas e os protótipos do GenBank variou entre 95-98\%. No presente estudo, a padronização e validação de uma multiplex-nested-PCR foi realizada com sucesso, utilizando protocolos simples, reprodutíveis, agrupamento dos sete controles positivos em um único plasmídeo bacteriano e substituição da detecção do material amplificado pela eletroforese capilar, mais rápida, barata e com maior grau de resolução que os géis de agarose. Para a implantação da técnica na rotina laboratorial, pretende-se a substituição do sequenciamento como método confirmatório, pela realização de amplificações em tempo real com Sybr Green, apenas do patógeno que for detectado pela multiplex-nested-PCR.

Descritores: Reação em cadeia por polimerase. Doenças infecciosas. Gestantes. Líquido amniótico. Sequenciamento genético. 


\begin{abstract}
Yamamoto L. Development of a multiplex-nested-PCR for the simultaneous detection of seven pathogens with DNA in their genomes in suspected cases of congenital infections. [thesis]. São Paulo: Instituto de Medicina Tropical de São Paulo da Universidade de São Paulo; 2016.

In Brazil, there was a significant reduction in infant mortality, but not in the perinatal component, which corresponds to $13 \%$ of the total. Diagnosis of congenital infections based on maternal clinical, ultrasonographic and serological data is very difficult, requiring a large number of serologies, some of which are not available in the laboratory routine, and the simple finding of a positive IgM and IgG in the pregnant woman does not constitute unequivocal evidence of vertical transmission. The extraction of DNA/RNA from amniotic fluid samples has a low yield, making it difficult to perform many molecular tests. Therefore, in the attempt to fill this diagnostic gap, the present research aimed to standardize and validate a multiplex-nested-PCR capable of simultaneously detecting seven pathogens that cause congenital infections and have DNA in their genomes: CMV, HSV, VZV, EBV, adenovirus, parvovirus B19 and Toxoplasma gondii, with determination of the relative frequency of each microorganism in a group of pregnant women with (study) or without suspicion of infection (control). In the study group, 147 pregnant women were recruited, with 57 positive cases (38.8\%): 32 with $T$. gondii ( $21.8 \%$ of the total and $56.1 \%$ of the positive ones), 12 with CMV (8.1\% and $21 \%$ ); 5 cases with parvovirus (3.4\% and $8.8 \%)$; 4 cases with adenovírus $(2.7 \%$ and $7 \%)$, and 4 cases with double detection ( 2 cases with T. gondii and CMV, 1 case with $T$. gondii and VZV, and 1 case with CMV and parvovirus). The control group had 193 cases and 197 samples: amniotic fluid for karyotyping in pregnant women with advanced age $(n=44)$; blood samples $(n=150)$, and fragments of placentas $(n=3)$ of pregnant women with normal prenatal care, at delivery. In this group, two amniotic fluid samples were positive (1.04\% of total cases and $4.5 \%$ of fluids): one case of adenovirus with normal fetal karyotype, and one case of $T$. gondii with increased nuchal translucency and trisomy 21 (Down syndrome). In this control group, 13/193 fetal karyotypes were altered (6.7\%). The lack of similar studies made it difficult to compare the results, but the multiplexnested-PCR detected a number almost six times higher than that detected by the tests available at the participating centers. All positive results were confirmed by sequencing the amplification products. The similarity between the amplified sequences and the GenBank prototypes varied between $95-98 \%$. In the present study, the standardization and validation of a multiplex-nested-PCR was performed successfully, using simple, reproducible protocols, clustering of the seven positive controls on a single bacterial plasmid and replacement of the amplification products detection by agarose gels for capillary electrophoresis, which is faster, cheaper and has a higher degree of resolution. For the implantation of the technique in the laboratory routine, it is intended the substitution of the sequencing as a confirmatory method, by the use of real-time amplifications with Sybr Green, only of the pathogen that has been detected by the multiplex-nested-PCR.
\end{abstract}

Keywords: Polymerase chain reaction. Infectious diseases. Pregnants. Amniotic liquid. Genetic sequencing. 


\section{LISTA DE ILUSTRAÇÕES}

Figura 1 - Número total de amostras do grupo de estudo distribuídos de acordo com o tipo de material analisado, e os patógenos detectados pela técnica de multiplex-nested-PCR, além da porcentagem relativa. .25

Figura 2 - Amostras biológicas e os patógenos encontrados pela técnica de multiplexnested-PCR no grupo controle... 


\section{LISTA DE TABELAS}

Tabela 1 -. Estimativa mundial da prevalência de infecções TORCH por 100.000 nascidos vivos.

Tabela 2 - Manifestações clínicas das infecções congênitas. .4

Tabela 3 - Alterações consideradas para a inclusão de casos no grupo de estudo, número de gestantes incluídas frequência.

Tabela 4 - Alterações ultrassonográficas encontradas nas gestantes do grupo de estudo e porcentagem relativa. .23

Tabela 5 - Critérios de inclusão das gestantes do grupo controle e porcentagem relativa.

Tabela 6 - Descrição do número de casos positivos por multiplex-nested-PCR ( $\mathrm{n}=57$ ) de acordo com o patógeno, e as respectivas alterações clínicas, laboratoriais e de exames subsidiários. 
$260 / 280$

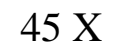

Comprimento de ondas do espectrofotômetro utilizadas para quantificação de ácidos nucleícos.

Cariótipo com Síndrome de Turner

Cariótipo com mosaicismo

Cariótipo feminino com translocação dos cromossomos 18 e 21

Cariótipo feminino com deleção no cromossomo 11

Cariótipo feminino com inversão no cromossomo 9

Cariótipo masculino com deleção no cromossomo 22

Cariótipo feminino com trissomia do cromossomo 13

Cariótipo masculino com trissomia do cromossomo 18

Cariótipo triplóide

Adenovírus

programa Basic Local Alignment Search Tool

Citomegalovírus

Ácido desoxirribonucleíco

Mix de nucleotídeos

Vírus Epstein-barr

Ácido etilenodiamino tetra-acético

Estados Unidos da América

Enterovírus

Hospital das Clínicas da Faculdade de Medicina da Universidade de São Paulo

Herpes vírus Humano 6

Herpes vírus Humano 7

Herpes vírus Humano 8

Vírus da imunodeficiência

Antígeno leucocitário humano

Herpes simplex tipo I e tipo II

Imunoglobulina da classe $\mathrm{G}$

Imunoglobulina da classe $\mathbf{M}$

Cloreto de Magnésio

Reação de cadeia em polimerase

Pré natal

Parvovírus B19

Recém-nascido

Ácido ribonucleíco 
RSV

Rub

T.gondii

Th1

Th2

VZV
Vírus sincicial respiratório

Vírus da rubéola

Parasito Toxoplasma gondii

Linfócito T helper 1

Linfócito T helper 2

Vírus varicela zoster 


\section{LISTA DE SÍMBOLOS}

$\begin{array}{ll}\% & \text { Porcentagem } \\ < & \text { Menor } \\ > & \text { Maior } \\ g & \text { Unidade de centrifugação } \\ \mathrm{mg} & \text { Miligramas } \\ \mathrm{mM} & \text { Milimolar } \\ \mathrm{ng} & \text { Nanogramas } \\ \mathrm{nm} & \text { Nanometro } \\ { }^{\circ} \mathrm{C} & \text { Graus Celsius } \\ \mathrm{pb} & \text { Pares de bases } \\ \mathrm{pH} & \text { Potencial hidrogeniônico } \\ \mathrm{UV} & \text { ultravioleta } \\ \mu \mathrm{g} & \text { Micrograma } \\ \mu \mathrm{L} & \text { Microlitro } \\ \mu \mathrm{M} & \text { Micromolar }\end{array}$




\section{SUMÁRIO}

1 INTRODUÇÃ

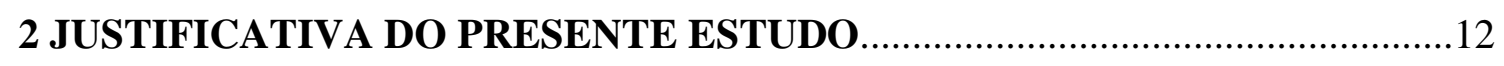

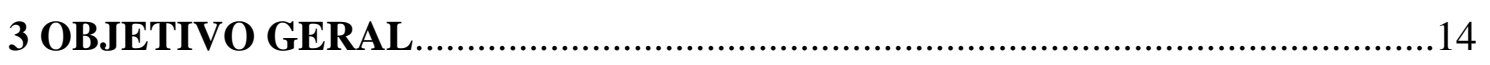

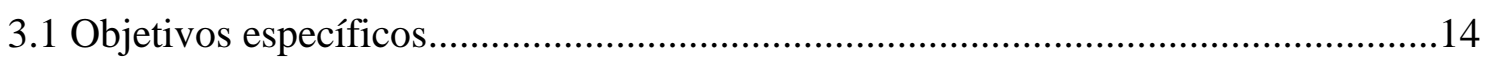

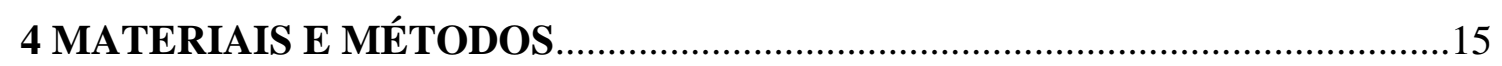

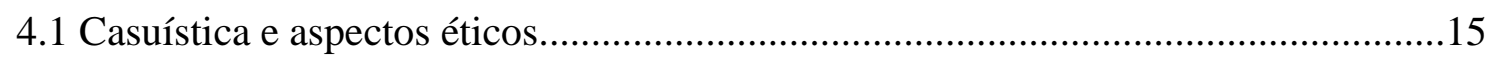

4.2 Critérios de inclusão das gestantes no grupo de estudo ........................................15

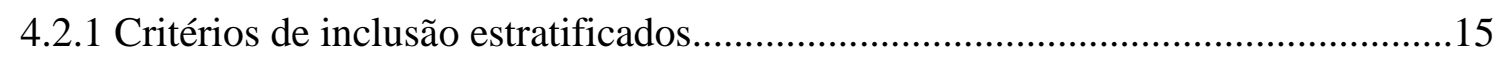

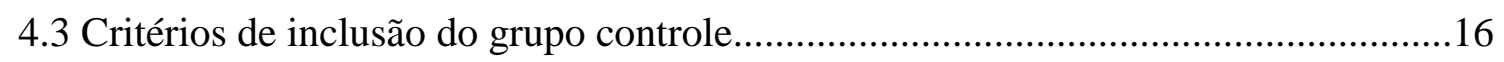

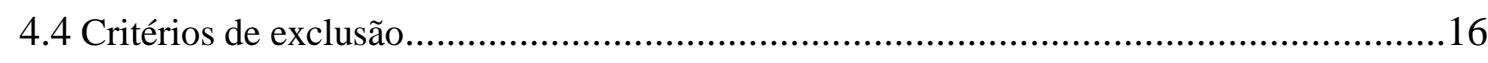

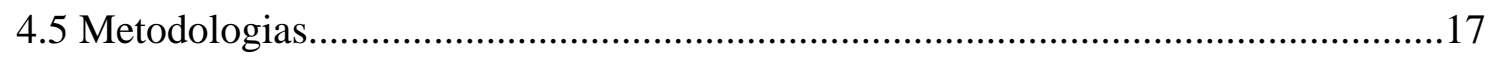

4.5.1 Colheita de líquido amniótico por meio de amniocentese guiada por ultrassom (grupo de estudo e grupo controle) ................................................................. 17

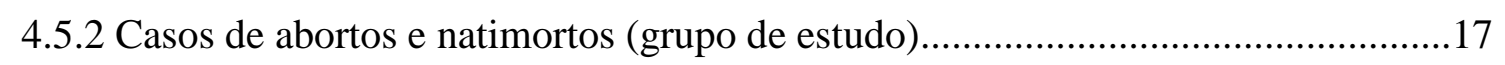

4.5.3 Colheita de sangue, urina e líquido cefalorraquidiano de recém-nascido (grupo de

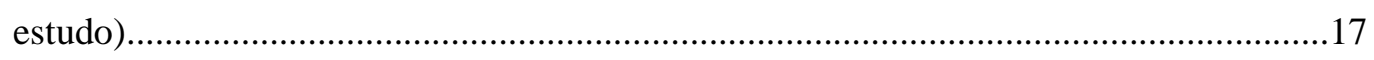

4.5.4 Colheita de sangue fetal da placenta nos partos normais (grupo controle)..........17

4.5.5 Extração de DNA a partir de sangue fetal, líquido amniótico, material de abortos espontâneos, natimortos, placentas, líquido cefalorraquidiano e urina de recém-

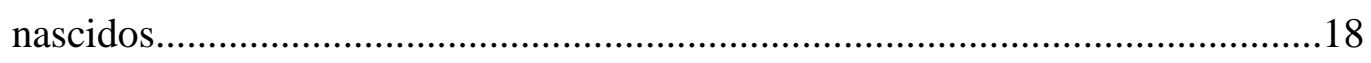

4.5.6 Determinação da concentração de DNA nas amostras.........................................18

4.5.7 Verificação da qualidade das amostras de DNA e inexistência de inibidores da amplificação. 


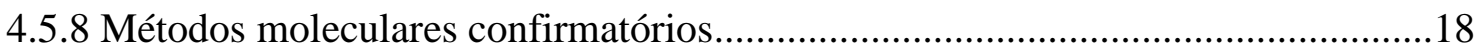

4.5.9. Primers selecionados para a multiplex-nested-PCR ...........................................18

4.5.10 Protocolo de amplificação da multiplex-nested-PCR.........................................19

4.5.11 Construção do controle positivo da multiplex-nested-PCR ................................19

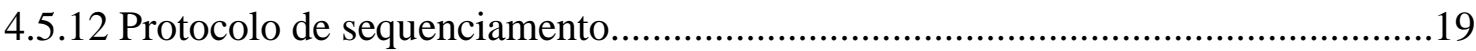

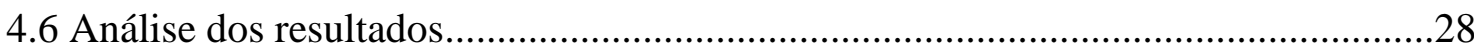

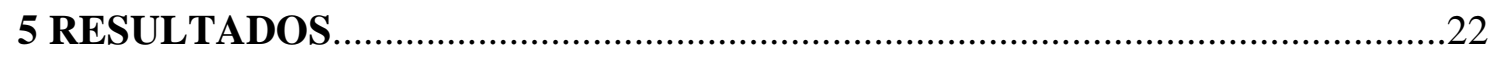

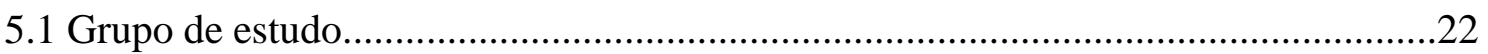

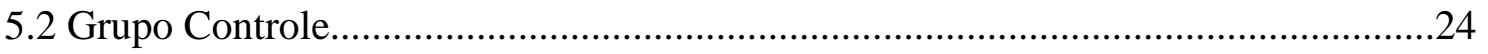

5.3 Resultados da multiplex-nested-PCR no grupo de estudo.....................................24

5.4 Resultados da multiplex-nested-PCR no grupo controle.......................................26

5.5 Resultados do sequenciamento automatizado dos fragmentos detectados pela

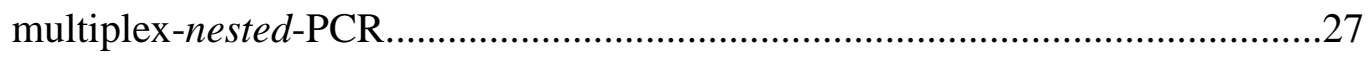

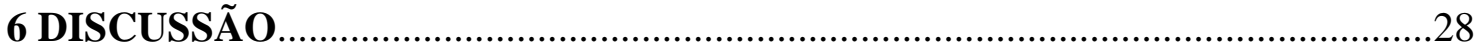

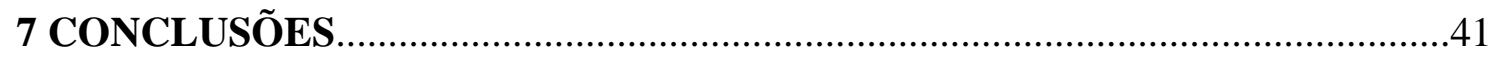

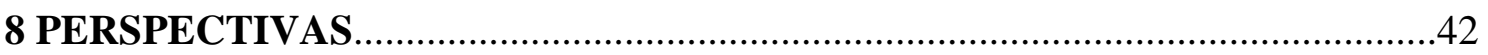

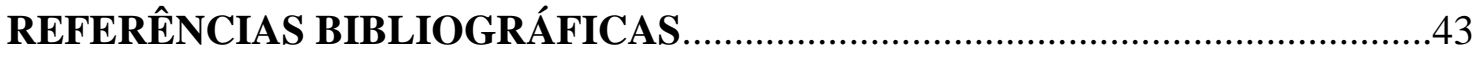

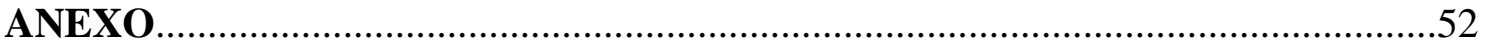




\section{INTRODUÇÃO}

A análise dos indicadores demográficos brasileiros permite observar que há algumas décadas vem ocorrendo redução da mortalidade infantil devido à identificação de causas evitáveis de morte tais como as doenças infecciosas. Sendo assim, houve significativa redução da mortalidade infantil, porém a mortalidade neonatal (0-28 dias de vida) e em especial a perinatal, isto é, aquela que ocorre da $22^{\mathrm{a}}$ semana de gestação até o sétimo dia de vida, não apresentaram redução. A mortalidade perinatal ainda se encontra na faixa dos 17 casos por 1.000 nascidos vivos no Estado de São Paulo, contrastando com os 5-9 casos/ 1.000 em países com maior grau de aparelhamento do sistema de saúde.

No Brasil, dentre as principais causas de mortalidade perinatal ganham destaque as "afecções perinatais" que correspondem a mais de $70 \%$ do total de óbitos nessa faixa etária, e a $50 \%$ dos óbitos que ocorrem no primeiro ano de vida. As infecções congênitas e perinatais corresponderiam a $13 \%$ deste contingente, e esta porcentagem tem se mantido ao longo do tempo, apesar do aprimoramento da qualidade de assistência pré-natal, ao parto e ao recém-nascido $o^{1,2,3,4,5,6,7,8}$.

O parasito Toxoplasma gondii, o vírus da rubéola, o citomegalovírus (CMV) e o herpes simplex (HSV) são agentes etiológicos há muito tempo reconhecidos como causadores de infecções congênitas. O acrônimo TORCH (Toxoplasma gondii, Outras infecções, Rubéola, Citomegalovírus e Herpes simplex) agrupava originalmente estes quatro patógenos, tendo sido proposto por Nahmias et al. ${ }^{9}$, na tentativa de padronizar a investigação diagnóstica em recém-nascidos gravemente enfermos com suspeita de infecção congênita. Desde então, este acrônimo tem sofrido expansão, com a inclusão do Treponema pallidum, parvovírus B19, vírus da hepatite B e de alguns RNA vírus tais como o HIV, enterovírus ${ }^{10}$, e mais recentemente os arbovírus (vírus da dengue, vírus da febre chikungunya e o zika vírus) ${ }^{11}$.

Mas o que é exatamente uma infecção TORCH? Embora não exista uma definição universal do que constitui uma infecção TORCH, as várias descrições usadas para este termo possuem muitos fatores em comum. Todos os agentes de infecções TORCH podem infectar mulheres durante a gestação. Tipicamente, mas nem sempre, 
estão presentes na corrente sanguínea materna causando viremia, bacteremia ou parasitemia. Muitas vezes não produzem doença significativa ou mesmo sintomas na gestante, porém são caracterizados por terem a capacidade de serem transmitidos verticalmente para o feto, na maioria das vezes por via hematogênica através da placenta, antes do parto ou, menos frequentemente, no período que antecede o parto e no momento do parto. Uma vez transmitidos aos fetos, os agentes TORCH podem causar uma variedade de complicações potencialmente graves, incluindo microcefalia, hidrocefalia, calcificações cerebrais, retinocoroidite (ou coriorretinite), doença multiorgânica (sistêmica), várias malformações congênitas (cardíacas, oculares, sistema nervoso, extremidades) e restrição de crescimento intrauterino. Os agentes TORCH também podem causar abortos espontâneos, natimortos e óbitos neonatais. O grau de acometimento fetal depende de vários fatores tais como a idade gestacional na qual o feto foi infectado e principalmente que órgãos e sistemas estavam sendo desenvolvidos naquele momento; a patogenicidade do microrganismo (tipo de cepa); fatores relacionados à predisposição genética do hospedeiro associados ou não ao complexo principal de histocompatibilidade (MHC) ou Human Leukocyte Antigen HLA $^{12,13}$, porém, sabe-se que várias infecções TORCH têm uma predileção pelo sistema nervoso central, causando alterações graves no cérebro, anormalidades estruturais neurológicas, resultando a longo prazo em atraso do desenvolvimento neuropsicomotor da criança ${ }^{14}$.

A epidemiologia das infecções do grupo TORCH varia significativamente, e em países de baixa e média renda, onde a prevalência destas infecções é maior, elas constituem os principais fatores associados à morbidade e mortalidade pré-natal e infantil $^{14}$ (Tabela 1). 
Tabela 1 - Estimativa mundial da prevalência de infecções TORCH por 100.000 nascidos vivos.

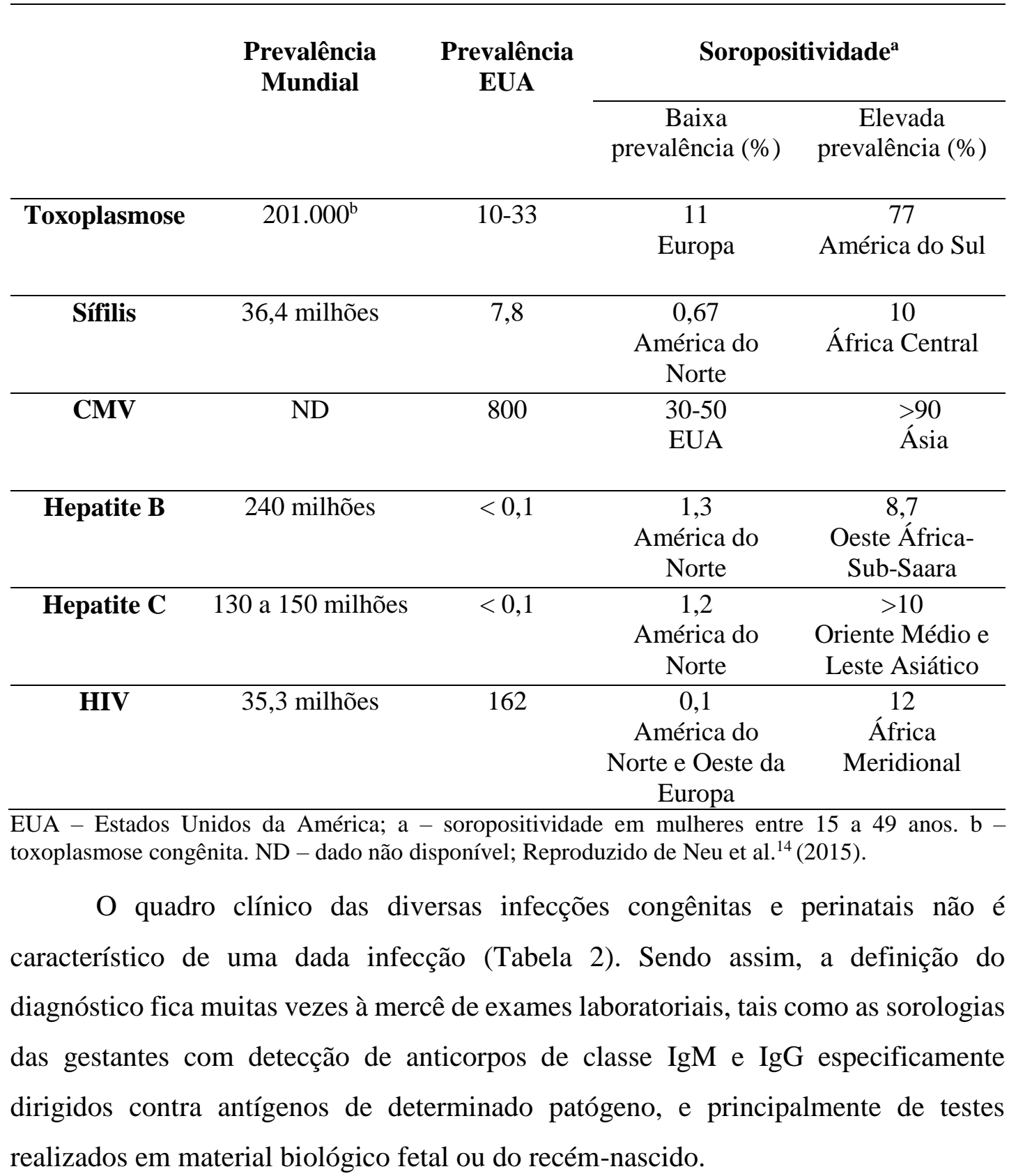


Tabela 2 - Manifestações clínicas das infecções congênitas. Reproduzido de Maldonado YA et $\mathrm{al}^{15}$ (2016). * modificado neste estudo.

\begin{tabular}{|c|c|c|c|c|c|c|}
\hline Sinal/sintoma & Rub & CMV & T. gondii & $\mathrm{HSV}$ & T. pallidum & $\mathrm{EV}$ \\
\hline Hepatoesplenomegalia & + & + & + & + & + & + \\
\hline Icterícia & + & + & + & + & + & + \\
\hline Pneumonite & + & + & + & + & + & + \\
\hline Petéquia ou púrpura & + & + & + & + & + & + \\
\hline Meningoencefalite & + & + & + & + & + & + \\
\hline $\begin{array}{l}\text { Coriorretinite ou } \\
\text { retinocoroidite }\end{array}$ & + & + & + & + & + & - \\
\hline Hidrocefalia & + & + & + & + & - & - \\
\hline Miocardite & + & - & + & + & - & + \\
\hline Exantema & - & - & + & + & + & + \\
\hline Microcefalia & $*_{+}$ & + & + & + & - & - \\
\hline Catarata & + & - & + & + & - & - \\
\hline Adenomegalia & + & - & - & - & + & + \\
\hline Calcificação intracraniana & - & + & + & - & - & - \\
\hline Surdez neurossensorial & + & + & - & - & - & - \\
\hline Lesões ósseas & + & - & + & - & + & - \\
\hline Glaucoma & + & - & - & - & + & - \\
\hline Microftalmia & + & - & + & - & - & - \\
\hline Atrofia de nervo ótico & - & + & + & - & - & - \\
\hline Uveíte & - & - & + & - & + & - \\
\hline Conjuntivite/ceratoconjuntivite & - & - & - & + & - & + \\
\hline Malformações congênitas & + & - & - & - & - & - \\
\hline Vesículas & - & - & - & + & - & - \\
\hline Paralisia (verdadeira) & - & - & - & - & - & + \\
\hline
\end{tabular}

Rub - vírus da rubéola; CMV - citomegalovírus; T. gondii - Toxoplasma gondii; HSV - herpes simplex vírus; T. pallidum - Treponema pallidum; EV - enterovírus; + presença; - ausência. * alteração introduzida neste estudo.

Grandes avanços tecnológicos foram alcançados nas metodologias voltadas à investigação de infecções. Desta forma, os métodos moleculares foram pouco a pouco incorporados à rotina diagnóstica de infecções congênitas, e dentre elas, a Reação em 
Cadeia da Polimerase (Polymerase Chain Reaction - PCR) tem sido a mais empregada $^{15}$. Desde os anos 2000, devido a maior sensibilidade, especificidade e valor preditivo positivo, a PCR começou a ser realizada em líquido amniótico e com menor frequência em sangue fetal e em fragmentos de placenta, passando a constituir o "padrão ouro" do diagnóstico laboratorial de várias das infecções congênitas, como por exemplo a toxoplasmose ${ }^{16,17}$. Fragmentos de placenta também podem ser úteis para o diagnóstico de infecções congênitas quando analisadas pela Reação em Cadeia da Polimerase (PCR), desde que exista associação das alterações placentárias encontradas e resultados da PCR com a sintomatologia fetal ${ }^{18,19,20,21}$. Entretanto, essa rotina diagnóstica não é seguida em nosso país devido a inúmeros fatores, tais como o elevado custo de reagentes e equipamentos para a realização dos testes moleculares, falta de centros de referência com recursos humanos capacitados, e inexistência de kits comerciais que possam identificar um grande número de microrganismos de forma simultânea, fator de grande importância considerando a quantidade diminuta de plasma/soro provenientes de sangue fetal, e de DNA e RNA extraídos de amostras de líquido amniótico.

Outro fator que dificulta o diagnóstico das infecções congênitas e perinatais é o fato de não ser suficiente confirmar a presença de infecção aguda na gestante, uma vez que a transmissão vertical do microrganismo, por via placentária, ao feto pode não ocorrer. Para que o diagnóstico seja confirmado, caso só sejam empregados métodos sorológicos, é necessário aguardar o nascimento da criança, e realizar o acompanhamento sorológico, ao menos até o final do primeiro ano de vida nos casos em que o recém-nascido não apresente anticorpos $\operatorname{IgM}$ ao nascimento. Este é um dos principais fatores que fazem com que as suspeitas diagnósticas de infecção congênita sejam feitas no período antenatal, porém o número de casos nos quais a confirmação do diagnóstico ocorre é desproporcionalmente mais baixo. Consequentemente, o teste molecular ideal deveria ser capaz de definir o diagnóstico laboratorial após uma única consulta, e ainda dentro do período antenatal, possibilitando intervenções médicas tais como o tratamento de algumas das infecções, como por exemplo, a toxoplasmose.

Dentre as infecções que podem ser transmitidas das gestantes aos seus conceptos, a mais frequente mundialmente é a citomegalovirose, causada pelo citomegalovírus (CMV), pertencente à família dos herpes vírus. O CMV é excretado 
na urina de $1 \%$ dos recém-nascidos, e a infecção pode estar presente em até $2,2 \%$ de todos os nascidos vivos, na maior parte dos casos de forma assintomática. Esta prevalência em diferentes populações depende de inúmeros fatores incluindo condições sócio-econômicas ${ }^{22,23,24,10}$.

Outros representantes da família dos herpes vírus tais como o Herpes simplex tipo I e II (HSV I e II), Varicela zoster (VZV), vírus Epstein-Barr (EBV), Herpes vírus humano 6 (HHV 6), HHV 7 e HHV 8 já foram identificados em infecções congênitas e perinatais, porém com menor frequência ${ }^{25}$. A maior parte dos casos de infecção causada pelo HSV ocorre no período perinatal e pós-natal. Os casos de infecção vertical (antenatal, congênita) são muito menos frequentes, correspondendo a cerca de $5 \%$ do total de casos, entretanto, costumam corresponder aos casos de maior gravidade. O maior risco de transmissão do HSV tipo I ou tipo II para o feto ocorre em vigência de primo-infecção durante a gestação (surto primário), e estima-se que 30-50\% dos fetos possam ser acometidos. Em caso de gestantes portadoras crônicas do vírus apresentando quadros de recorrência, a probabilidade de acometimento fetal é bem menor (1 a 4\%). A frequência relativa de doença herpética neonatal é de 1: 3.000 a 1: 7.500 nascidos vivos podendo acarretar abortamentos, lesões graves de sistema nervoso central, notadamente encefalites, prematuridade, dentre outras alterações ${ }^{10,15}$.

$\mathrm{O}$ vírus varicela zoster $(\mathrm{VZV})$ acomete mais raramente fetos e recém-nascidos (1-5 casos/10.000 nascidos vivos). O risco de infecção materna, e de infecção fetal grave parece ser maior na varicela (infecção primária), que no herpes zoster (reativação do vírus) provavelmente devido à maior viremia podendo causar crescimento intrauterino restrito e malformações congênitas. Estas últimas, estariam relacionadas a hipoplasia de membros, pé torto congênito, microcefalia, microftalmia, catarata, coriorretinite, paralisias motoras, atresias intestinais, dentre outras alterações $^{26}$.

Dentre os parasitos que podem causar infecções congênitas, o mais frequentemente encontrado é o Toxoplasma gondii. A ocorrência de toxoplasmose congênita varia de acordo com condições sócio-econômicas, hábitos alimentares e contato com animais, principalmente gatos ${ }^{15}$. No Brasil, 50-80\% das mulheres em idade fértil apresentam anticorpos anti-T. gondii, porém esta positividade sorológica parece estar sofrendo redução nas últimas décadas. O risco para mulheres não imunes 
de adquirirem toxoplasmose durante a gravidez e transmitirem a infecção ao feto é elevado, uma vez que o meio ambiente é altamente contaminado com oocistos do parasito. O ônus médico e social da toxoplasmose em crianças infectadas congenitamente também é muito elevado. Rastreamento sorológico para $T$. gondii com detecção de IgM realizado em recém-nascidos revelou a existência de 5-23 crianças infectadas/10.000 nascidos vivos em nosso país. Se considerarmos uma criança infectada/1.000 nascidos vivos, teríamos um contingente de 2.649 crianças com toxoplasmose congênita anualmente ${ }^{27}$. A transmissão de Toxoplasma gondii ao feto varia de acordo com a idade gestacional em que a infecção foi adquirida, sendo menos frequente durante o primeiro trimestre, chegando a mais de $65 \%$ no terceiro trimestre $^{28,29}$, porém causando lesões fetais de menor gravidade.

O parvovirus B19 é um DNA vírus que causa várias síndromes clínicas tais como o eritema infeccioso e crises de aplasia medular em portadores de anemia, podendo ser transmitido da gestante ao feto, causando hidropsia fetal não imune. Com relação à transmissão congênita, sabe-se que 45 a 75\% das gestantes são susceptíveis, e em vigência de infecção materna, a transmissão ao feto ocorre em cerca de $30 \%$ dos casos, sendo o risco de óbito fetal de aproximadamente $9 \%$

Com relação à detecção de adenovírus por PCR, por ser um agente viral menos conhecido como agente etiológico de infecções congênitas, tomamos a liberdade de discorrer mais longamente sobre os mesmos. O primeiro caso de hidropsia fetal atribuído ao adenovírus foi relatado por Towbin et al. ${ }^{33}$. A seguir, Ranucci-Weiss et al. ${ }^{34}$ descreveram o caso de feto na $27^{\mathrm{a}}$ semana com hidropsia fetal e taquiarritmia, alterações atribuídas a infecção por adenovírus, detectado por PCR. A arritmia cardíaca fetal foi revertida por meio de tratamento materno com digoxina, e na $29^{\text {a }}$ semana ocorreu parto prematuro, porém o recém-nascido apresentou aparência normal (não se encontrava mais hidrópico), indicando que a hidropsia estaria associada à insuficiência cardíaca. Este foi um dos primeiros casos documentados de infecção intrauterina associada ao adenovírus.

No mesmo ano, Forsnes et al. ${ }^{35}$ descreveram o caso de uma gestação gemelar em gestante de 25 anos, que referia um parto normal anteriormente. O ultrassom realizado na $20^{\mathrm{a}}$ semana revelou hidropsia em um dos fetos. Adenovírus foi detectado no líquido amniótico apenas do feto hidrópico, mas não no líquido amniótico do outro 
feto. $\mathrm{Na} 26^{\mathrm{a}}$ semana os dois fetos evoluíram a óbito. Este caso demonstra que a transmissão vertical do adenovírus pode ser diferenciada, tendo sido levantada a hipótese da hidropsia fetal identificada em um dos fetos ser secundária à infecção pelo adenovírus.

Oyer et al.$^{36}$ relataram o caso de um natimorto pesando 1.800 gramas, que havia realizado uma ultrassonografia uma semana antes e apresentava hidropsia, cardiomegalia, e possivelmente estenose de valva aórtica. A necropsia confirmou a hidropsia e a presença de estenose de valvas aórtica e pulmonar. O miocárdio apresentava áreas de fibrose focal e calcificação. As valvas e o miocárdio foram analisados por PCR e revelaram a presença de adenovírus. Este relato de caso chamou a atenção para a raridade da miocardite intrauterina, tendo sido a maior parte destes casos atribuídos ao vírus da rubéola, e com frequência muito menor ao Coxsackie vírus B (enterovírus), parvovírus B19 e ao adenovírus.

Baschat et al. ${ }^{37}$ analisaram a associação entre o encontro de DNA de adenovírus em líquido amniótico e o desfecho das gestações. Foram incluídas gestantes no segundo trimestre que realizaram amniocentese devido à suspeita de malformação fetal. As amostras foram analisadas por multiplex-PCR capaz de detectar um painel de vírus incluindo adenovírus. Fetos com cariótipo anormal foram excluídos do estudo. A prevalência de adenovírus no grupo de fetos normais (39/652 ou 6\%) em relação a fetos malformados (23/364 ou 6,3\%) foi comparável ( $\mathrm{p}=0,376)$. Anomalias de sistema nervoso central e focos ecogênicos em fígado foram mais frequentes no grupo com multiplex-PCR positiva para adenovírus $(\mathrm{p}<0,005)$. Os autores concluíram que a prevalência de adenovírus em fetos normais e malformados foi semelhante. Muito embora não tenham sido identificadas alterações específicas em fetos infectados por adenovírus, as lesões hepáticas ecogênicas com ou sem hidropsia fetal e defeitos de tubo neural foram mais comuns nos fetos com multiplex-PCR positiva para adenovírus.

Puerari et al. ${ }^{38}$ utilizaram testes de imunofluorescência direta e nested-PCR (primers do gene hexon) para a detecção de adenovírus em crianças com doenças cardíacas congênitas de possível etiologia viral $(n=123)$, e em crianças da comunidade apresentando quadros respiratórios agudos $(n=165)$. De um total de 288 amostras de material nasal, 209 foram incluídas no estudo, 43 (14,8\%) foram positivas em pelo 
menos um dos testes feitos: 17/165 (10,3\%) das crianças da comunidade e 26/125 $(20,8 \%)$ das cardiopatas. As taxas de detecção por nested-PCR foram 15/165 $(9,1 \%)$ em crianças da comunidade e 24/125 (19,2\%) em crianças cardiopatas. Os autores concluíram que o método molecular mostrou maiores taxas de detecção quando comparado à fluorescência $(p<0,001)$ e que o adenovírus parece estar associado a malformações cardíacas congênitas.

Existem estudos nos quais foi realizada a detecção de vários agentes virais, porém não de forma simultânea, em uma única PCR. McLean et al. ${ }^{39}$ estudaram a presença de genomas virais em gestações com baixo risco infeccioso. Amostras de líquido amniótico de 277 gestantes foram analisadas por PCR para a detecção de adenovírus, CMV, HSV e parvovírus B19. Nenhuma das amostras apresentou amplificação, e os autores concluíram que a presença de genomas virais em gestações que apresentem algum risco infeccioso apresenta significado clínico.

Van den Veyver et al. ${ }^{40}$ utilizaram uma PCR para avaliar a frequência de infecções virais em fetos com hidropsia não imune. Além de algumas causas já conhecidas de hidropsia fetal não imune tais como as infecções causadas pelo CMV e o parvovírus B19, foram investigados outros vírus: HSV, EBV, adenovírus, enterovírus, além do vírus sincicial respiratório (RSV) em amostras de líquido amniótico, sangue, líquido pleural e tecidos fetais. Foram incluídos 303 casos de hidropsia fetal e 154 controles. Genomas virais foram encontrados em 124 de 303 fetos com hidropsia (41\%). Adenovírus foi o vírus mais frequente, detectado em 74 fetos (24\%), CMV em 30 (10\%), e enterovírus em 22 fetos (7\%). No grupo controle foram encontrados 4 fetos com PCR positiva (4/154 ou 2,6\%). Os autores concluíram que a detecção de genomas virais é frequente em gestações anormais, e que adenovírus e enterovírus, além do CMV e parvovírus, podem causar infecções, resultando em fetos hidrópicos. Sobre o achado de 2,6\% de PCR positiva no grupo controle, os autores argumentaram que em todas as gestações nas quais houver PCR positiva para agentes virais, seria imperativo que a investigação de infecções virais e de alterações fetais fosse aprofundada. Esta argumentação foi embasada pelo estudo anterior conduzido por McLean et al. ${ }^{39}$.

Baschat et al. ${ }^{41}$ investigaram, por PCR, a presença de genomas virais em 686 amostras de líquido amniótico colhidas no segundo trimestre de gestantes com 
ultrassom fetal e cariótipo normais. DNA extraído de líquido amniótico foi analisado por multiplex-PCR para a detecção de CMV, HSV, EBV, parvovírus B19, adenovírus, assim como de alguns RNA vírus (enterovírus e vírus sincicial respiratório). Foram encontradas 44 amostras positivas (44/686 ou 6,4\%). Em 41 destas 44 amostras $(93,2 \%)$ apenas um vírus foi detectado, e em três casos dois vírus foram detectados. Os adenovírus foram os mais frequentes (37/44 ou 84,1\%), seguidos do CMV (5 casos), EBV (2 casos), enterovírus (2 casos) e sincicial respiratório (1 caso). Parvovírus B19 e HSV não foram encontrados nesta casuística. O estudo concluiu que o encontro de genomas virais em amostras de líquido amniótico é relativamente comum em fetos com ultrassom e cariótipo normais, e a prevalência segue uma distribuição sazonal, mas o significado destes resultados necessita de investigações mais aprofundadas.

O estudo de Reddy et al. ${ }^{42}$ teve como objetivo verificar se a detecção de genomas virais em amostras de líquido amniótico estaria associada a gestações com desfecho anormal. Para tanto, foram investigados os seguintes vírus: CMV, HSV, EBV, parvovírus B19, adenovírus, além de alguns RNA vírus, tais como os enterovírus e o vírus sincicial respiratório. Foram analisados 423 líquidos amnióticos, e 57 (13,5\%) foram positivos por PCR: adenovírus (78\%), enterovírus (12\%), CMV (5\%) e parvovírus B19 (5\%). Dos casos com ultrassom fetal anormal, 24\% tiveram PCR positiva, comparados a 8,4\% daqueles com ultrassom normal. Os autores concluíram que a PCR positiva em líquido amniótico estaria associada a uma taxa aumentada de malformações fetais estruturais, crescimento intrauterino restrito, hidropsia fetal, dentre outras anomalias fetais.

Fritsch et al. ${ }^{43}$ investigaram retrospectivamente 116 casos de hidropsia fetal não imune, sendo que 91 casos $(78,5 \%)$ tiveram a etiologia elucidada, e 25 casos $(21,5 \%)$ foram classificados como idiopáticos. Anomalias cromossômicas foram as mais frequentes (26 casos ou 22,4\%), seguidas de malformações do sistema linfático, tais como higroma cístico, responsável por 11 dos 15 casos (12,9\%), alterações cardiovasculares (14 casos ou 12,1\%) e etiologia infecciosa em 14 fetos $(12,1 \%)$. Dentre os 14 casos com etiologia infecciosa, o parvovírus B19 foi responsável por 6 casos, Toxoplasma gondii $(\mathrm{n}=3)$, CMV $(\mathrm{n}=3)$, HSV $(\mathrm{n}=1)$ e Treponema pallidum $(\mathrm{n}=1)$. Os autores concluíram que o esclarecimento da etiologia da hidropsia fetal é 
particularmente importante nos casos associados a agentes infecciosos, uma vez que algumas destas infecções podem ser tratadas.

Existem poucos estudos até o momento que utilizaram multiplex-PCR para a detecção simultânea de vários agentes etiológicos associados a infecções congênitas. McIver et al. ${ }^{44}$ desenvolveram quatro sistemas distintos do tipo multiplex-nested-PCR (1, 2, 3 e 5) para a detecção de agentes com DNA no genoma: CMV, HSV tipo I e tipo II, varicela zoster, EBV, herpes vírus 6, 7 e 8 e parvovírus B19; e com RNA no genoma: enterovírus; vírus da hepatite $\mathrm{C}$; vírus causador da meningite linfocítica (arenavírus) e vírus da rubéola. Os autores também incluíram o parasito Toxoplasma gondii, devido a sua importância na gênese de infecções congênitas. Todas as quatro multiplex-nested-PCR apresentaram limite de detecção (sensibilidade analítica) de 20200 cópias virais, e no caso de Toxoplasma gondii, detecção de 2 cópias do fragmento alvo da amplificação, do gene B1 do parasito. A taxa de detecção dos dois melhores sistemas, dentre os quatro testados foi de 13,5 e 22,2\%, e os resultados positivos foram confirmados pelos resultados de isolamento viral e sorologias para a maior parte dos patógenos.

Adams et al. ${ }^{45}$ procuraram determinar se alterações ultrassonográficas fetais deveriam ser usadas para indicar a pesquisa de genomas virais em amostras de líquido amniótico. As amostras foram testadas por multiplex-PCR para a detecção de genomas virais, a saber, adenovírus, CMV, EBV, parvovírus B19, enterovírus e vírus sincicial respiratório. As ultrassonografias foram classificadas como normais ou anormais (34 categorias e 18 subgrupos) e foram analisadas associações entre estes subgrupos e os resultados de cariótipo e PCR. De um total de 1.191 amostras de líquido amniótico, cariótipo anormal foi detectado em 5,4\% (64/1.191) e PCR positiva em 6,5\% (71/1.191). Alterações ultrassonográficas ocorreram em 28,4\% dos casos (338/1.191). Foi encontrada associação entre PCR positiva e crescimento intrauterino restrito, hidropsia fetal não-imune, anomalias de mãos e pés, e defeitos de tubo neural (em fetos com cariótipo normal e espessamento nucal). Os autores concluíram que amostras de líquido amniótico deveriam ser analisadas por PCR para a pesquisa de genomas virais em fetos com crescimento intrauterino restrito, hidropsia fetal não-imune, anomalias de mãos e pés e defeitos de tubo neural. 


\section{JUSTIFICATIVA DO PRESENTE ESTUDO}

A primeira consideração a ser feita é que não é possível definir o diagnóstico de infecções congênitas com base apenas em sinais e sintomas na gestante, e até mesmo pelos resultados sorológicos maternos, uma vez que infecção pode não ter sido transmitida ao feto.

A triagem sorológica para muitas infecções é realizada de forma rotineira durante a gestação no âmbito do atendimento pré-natal: Toxoplasma gondii, vírus da rubéola, parvovírus B19, herpes simplex, são investigados por metodologia sensível e automatizada (imunoenzimática, imunofluorimetria, quimioluminescência), além dos resultados positivos serem confirmados por testes de imunofluorescência ou captura de IgM. No entanto, mesmo em grandes centros de referência tais como o Hospital das Clínicas de São Paulo e o Hospital e Maternidade Vila Nova Cachoeirinha, alguns microrganismos que são considerados importantes no contexto das infecções congênitas, não são investigados sorologicamente de forma rotineira, tais como os adenovírus e os enterovírus.

Até recentemente, o rastreamento sorológico de gestantes para o CMV não era realizado de forma sistemática por todos os centros de atendimento pré-natal, havendo controvérsia sobre a utilidade do mesmo enquanto não existir consenso sobre o tratamento materno e fetal com antivirais (ganciclovir ou aciclovir) ou com a gamaglobulina hiperimune, esta última opção, com custo extremamente elevado ${ }^{46,47}$.

Considerando todos os argumentados citados, não seria descabido, tanto do ponto de vista assistencial, quanto em termos de custo-efetividade, propor a realização de duas amplificações que pudessem detectar sete patógenos que já foram associados a infecções congênitas e que contêm DNA no genoma, de forma simultânea.

Muito embora alguns testes moleculares necessários à investigação de infecções congênitas sejam disponibilizados em centros terciários de atendimento médico, existe, via-de-regra, escassez de material biológico (líquido amniótico/ sangue fetal) para a realização de vários testes moleculares, se forem realizados um a um. É preciso lembrar que a extração de DNA partindo de amostras de líquido amniótico, em geral, resulta em baixíssimas concentrações de DNA. Desta forma, seria muito mais rápido e eficaz, além de gerar economia de material biológico, reagentes e recursos humanos, dispor de testes combinados voltados à investigação de várias infecções 
congênitas de forma simultânea, desde que não exista perda de sensibilidade e especificidade. Ademais, devemos considerar que a situação atual com a realização de uma dezena de sorologias para uma única gestante e a necessidade de realização da sorologia fetal, do recém-nascido e em casos de $\operatorname{IgG}$ negativa ao nascimento, do lactente ao longo do primeiro ano de vida, também representaria um gasto significativo para o sistema público de saúde, além de uma perda crucial de tempo, não permitindo a elucidação diagnóstica ainda no período antenatal, impedindo o tratamento em alguns casos específicos. Também já foi citado que os sinais/sintomas das infecções congênitas são muito similares, dependendo consideravelmente da idade gestacional na qual o feto foi infectado, isto é, dos órgãos e sistemas fetais que estavam sendo desenvolvidos naquele momento, além da capacidade patogênica do microrganismo e da predisposição genética do hospedeiro ${ }^{12,13}$.

Sendo assim, o desenvolvimento de métodos diagnósticos com maior acurácia, sensibilidade e especificidade permitiria a elucidação de um número maior de infecções relacionadas à mortalidade perinatal, possibilitando a alocação de recursos públicos em medidas de melhor custo-efetividade. Em algumas situações, como por exemplo, nos casos de toxoplasmose congênita, existe tratamento para a gestante, reduzindo a morbimortalidade perinatal e as sequelas mais tardias, muitas vezes incapacitantes na criança e no adulto, tais como perda da acuidade visual podendo levar à cegueira; surdez neurosensorial profunda, e deficiência mental ${ }^{48}$.

Outro fato importante é que o levantamento que realizamos sobre os grupos de pesquisa que trabalham com o desenvolvimento de testes moleculares voltados ao diagnóstico de infecções congênitas apontou a existência de apenas um laboratório australiano $^{44}$, enfatizando a contribuição médica da presente proposta, o seu grau de ineditismo, e demonstrando o quanto o tema tem sido negligenciado, não apenas em nosso meio. Ademais existe potencial para o patenteamento da técnica que foi desenvolvida, e o seu uso para a triagem e o efetivo diagnóstico das infecções que são mais frequentemente transmitidas das gestantes aos seus fetos, causadas por patógenos que contêm DNA no genoma. 


\section{OBJETIVO GERAL:}

Identificar os principais patógenos que possuem DNA no genoma e causam infecções congênitas em casos suspeitos provenientes de centros de referência obstétricos da cidade de São Paulo, com o emprego de metodologia molecular.

\subsection{OBJETIVOS ESPECÍFICOS:}

- Padronizar um sistema de detecção molecular do tipo multiplex-nested-PCR para a detecção simultânea de sete patógenos que possuem DNA no genoma;

- Validar a multiplex-nested-PCR por meio da avaliação de casos suspeitos e não suspeitos de infecção congênita provenientes de centros de referência obstétricos da cidade de São Paulo.

- Determinar a frequência das infecções congênitas que fazem parte desta pesquisa em dois centros de referência obstétricos da cidade de São Paulo. 


\section{MATERIAL E MÉTODOS}

\subsection{CASUÍSTICA E ASPECTOS ÉTICOS}

A casuística foi composta por gestantes alocadas no estudo de modo consecutivo. Elas foram atendidas no Serviço de Obstetrícia do HC/FMUSP e no Serviço de Obstetrícia do Hospital e Maternidade da Vila Nova Cachoeirinha no período de 2011 a 2014. A pesquisa foi aprovada pela Comissão para Análise de Projetos de Pesquisa (CAPPesq) da Diretoria Clínica do HC/FMUSP (ANEXO 1e 2). Trata-se, portanto, de uma casuística de conveniência, limitada pelo número de casos encaminhados aos serviços de obstetrícia participantes da pesquisa e que preencheram os critérios de inclusão do estudo.

\subsection{CRITÉRIOS DE INCLUSÃO DAS GESTANTES NO GRUPO DE ESTUDO}

No caso das gestantes do grupo de estudo, elas deveriam apresentar necessariamente suspeita clínica e/ou ultrassonográfica e/ou laboratorial (sorológica) de infecção congênita. Dessas gestantes foram colhidas amostras de líquido amniótico por meio de amniocentese guiada por ultrassonografia e realizada por médico obstetra, especialista em medicina fetal. Com menor frequência foram colhidas amostras de sangue fetal ou fragmentos de placenta na sala de parto (em vigência de sintomatologia fetal condizente com a presença de infecção, sempre de acordo com decisão do obstetra).

\subsubsection{CRITÉRIOS DE INCLUSÃO ESTRATIFICADOS}

a) Casos de óbito fetal sem co-morbidade associada;

b) Antecedente de natimortos sem co-morbidade associada;

c) Fetos com crescimento intrauterino restrito precoce (abaixo de 25 semanas), simétrico, abaixo do percentil 5, sem doença materna associada;

d) Alterações ultrassonográficas: ventriculomegalia, hidrocefalia, microcefalia, calcificações intracranianas, alterações oculares, calcificações hepáticas, hidropsia fetal não-imune, cardiomiopatia fetal, malformações cardíacas, malformações de extremidades (mãos e pés), malformações de sistema nervoso central não especificadas, defeitos do tubo neural, ascite, outros derrames intracavitários, higroma 
cístico, hepato-esplenomegalia, intestino ecogênico, placentomegalia, alterações do volume de líquido amniótico (oligoâmnio ou polidrâmnio sem doença materna associada);

e) Sorologia positiva (presença de $\operatorname{IgM}$ e IgG) para alguma das infecções congênitas que constituem objeto da presente pesquisa.

\subsection{CRITÉRIOS DE INCLUSÃO DO GRUPO CONTROLE}

O grupo controle foi constituído por gestantes seguidas no pré-natal "normal" dos dois centros participantes, com triagem sorológica negativa para as doenças infecciosas que são rotineiramente rastreadas em cada um dos centros. Dessas gestantes, foram obtidas amostras de sangue fetal colhidas da placenta no momento do parto.

Também fazendo parte do grupo controle foi recrutado um contingente de gestantes das quais foram obtidas amostras de líquido amniótico para cariotipagem. Tratava-se de gestantes com idade avançada e/ou suspeita de malformação fetal de origem cromossômica, porém sem suspeita de infecção (triagem sorológica sem alterações).

Foi necessário analisar um grupo controle de gestantes sem suspeita de infecção pelo fato de alguns relatos na literatura terem demonstrado presença de genomas virais em líquido amniótico e placentas de gestações assintomáticas e com desfecho normal, como foi citado na parte introdutória desta tese.

\subsection{CRITÉRIOS DE EXCLUSÃO:}

a) Não preenchimento dos critérios de inclusão;

b) Ser gestante portadora do HIV;

c) Recusa da gestante em participar da pesquisa;

d) Impossibilidade de colheita dos materiais biológicos necessários à realização da pesquisa. 


\subsection{METODOLOGIAS}

Nos casos suspeitos de CMV, toxoplasmose, rubéola, infecção por HSV tipo I e II, varicela zoster, foi realizada a investigação sorológica da gestante, porém a detecção do vírus da rubéola (RNA vírus) não constitui objeto de estudo da presente pesquisa. Nos casos suspeitos de adenovírus, devido à falta de uma triagem sorológica realizada no hospital de origem das gestantes, o teste molecular não contou com um teste sorológico de referência para comparação.

4.5.1 Colheita de líquido amniótico por meio de amniocentese guiada por ultrassom (grupo de estudo e grupo controle): após assinatura do Termo de Consentimento Livre e Esclarecido pela gestante, foram colhidos 3-5 mL de líquido amniótico para os testes moleculares. Eventualmente, sempre por indicação médica, foi feita cordocentese para obtenção de sangue fetal guiada por ultrassom nessas gestantes, em lugar da amniocentese.

4.5.2 Casos de abortos e natimortos (grupo de estudo): após a assinatura do Termo de Consentimento Livre e Esclarecido pela gestante foram colhidos fragmentos de tecidos fetais ou do natimorto e da placenta (dos locais onde havia alterações macroscópicas).

4.5.3 Colheita de sangue, urina e líquido cefalorraquidiano de recém-nascidos (grupo de estudo): após a assinatura do Termo de Consentimento Livre e Esclarecido pela gestante, foram colhidos 1-3 mL de sangue periférico do recém-nascido em tubo com EDTA, ou amostra de urina em recipiente estéril (volume mínimo de $3 \mathrm{~mL}$ ), ou ainda amostra de $1 \mathrm{~mL}$ de líquido cefalorraquidiano do recém-nascido em tubo estéril.

4.5.4 Colheita de sangue fetal da placenta nos partos normais (grupo controle): após a assinatura do Termo de Consentimento Livre e Esclarecido pela gestante, foram colhidos 1-3 mL de sangue diretamente da placenta após a dequitação, em tubo com EDTA. 
4.5.5 Extração de DNA a partir de sangue fetal, líquido amniótico, material de abortos espontâneos, natimortos, placentas, líquido cefalorraquidiano e urina de recém-nascidos. $\mathrm{O}$ procedimento de extração de DNA foi realizado com o kit de extração QIAamp DNA Mini Kit (QIAGEN Inc., Germany), de acordo com as recomendações do fabricante.

4.5.6 Determinação da concentração de DNA nas amostras. A estimativa da concentração de DNA foi realizada por espectrofotometria UV em comprimentos de onda de 260, 280 e $230 \mathrm{~nm}$ (Nanodrop 1000, Thermo Scientific, USA).

\subsubsection{Verificação da qualidade das amostras de DNA e inexistência de inibidores} da amplificação. Antes da realização da multiplex-nested-PCR e das amplificações confirmatórias, as amostras de DNA foram testadas com os primers $\beta 1$ (5'GTGGGGCGCCCCAGGCACCA-3'), e $\beta 2$ (5'- CTCCTTATTGTCACGCACGATT TC-3') do gene da $\beta$-actina humana, primers estes descritos por Nakajima-Iijima et al. ${ }^{49}$ que amplificam fragmento de $540 \mathrm{pb}$. A amplificação seguiu o seguinte protocolo: 40 ciclos de 1 minuto de desnaturação a $95^{\circ} \mathrm{C}, 1$ minuto de annealing a $45^{\circ} \mathrm{C}$ e 1 minuto de extensão a $72^{\circ} \mathrm{C}$. Em um microtubo de $0,2 \mathrm{~mL}$, considerando volume final da reação de $25 \mu \mathrm{L}$, foram usados $200 \mu \mathrm{M}$ de dNTP; 0,4 $\mu \mathrm{M}$ dos primers, 1,25 U da Taq DNA polimerase (Labtrade), tampão [10X] (Labtrade), 1,5 mM do $\mathrm{MgCl}_{2}$ (Labtrade).

4.5.8 Métodos moleculares confirmatórios: as amostras positivas pela multiplexnested-PCR, foram submetidas a uma PCR "em separado", isto é, realizada apenas com o par de primers do patógeno detectado pela multiplex-nested-PCR. Além disso, os fragmentos amplificados na $2^{\mathrm{a}}$ PCR da multiplex foram submetidos a sequenciamento automatizado. Esta medida foi necessária, ao menos na fase de validação da multiplex-nested-PCR durante a qual amostras de casos suspeitos foram testados, para garantir que os fragmentos amplificados correspondiam de fato ao alvo das amplificações.

4.5.9 Primers selecionados para a multiplex-nested-PCR: a reação final de multiplex-nested-PCR foi padronizada de maneira a ser capaz de amplificar os sete 
patógenos de forma simultânea. Esta composição final de sete patógenos a serem investigados em um único ensaio foi definida pela nossa equipe juntamente com especialistas em medicina fetal, de acordo com os patógenos provavelmente mais frequentes nos Serviços de Obstetrícia do HC/FMUSP, e também com base nos dados existentes em literatura que foram citados na parte introdutória.

4.5.10 Protocolo de amplificação da multiplex-nested-PCR: resumidamente, utilizando o Kit QIAGEN Multiplex PCR (QIAGEN, Germany) em reação com volume final de $25 \mu \mathrm{L}$.

4.5.11 Construção do controle positivo da multiplex-nested-PCR: um "gene sintético" foi construído para ser empregado como controle positivo da reação de multiplex-nested-PCR, evitando que em cada reação tivéssemos que preparar os sete controles positivos em separado.

Inicialmente, a detecção dos amplificados foi realizada por eletroforese horizontal em géis de agarose (Invitrogen, USA)/ nusieve, GTG/ Lonza, USA) e posteriormente por eletroforese capilar, considerando que existem amplificados com pesos moleculares muito próximos e que dificultam a diferenciação em géis de agarose.

4.5.12 Protocolo de sequenciamento: os produtos das amplificações foram purificados com o kit comercial "Wizard SV Gel and PCR Clean-up System" (PROMEGA, USA). A cada produto de PCR foi adicionado o mesmo volume do tampão "Membrane Binding Solution" e a solução foi transferida para uma coluna de afinidade acoplada a um microtubo. Após a incubação por 1 minuto em temperatura ambiente, a coluna foi centrifugada a $16.000 \times \mathrm{x}$ por 1 minuto e o sobrenadante foi descartado. A seguir, a coluna foi lavada com $700 \mu \mathrm{L}$ da solução "Membrane Wash Solution" por centrifugação a 16.000 x $g$ por 1 minuto. Posteriormente, a coluna foi novamente lavada com $500 \mu \mathrm{L}$ da solução "Membrane Wash Solution" por centrifugação a $16.000 \times \mathrm{x}$ por 5 minutos. A seguir, a coluna foi deixada em banho seco a $60^{\circ} \mathrm{C}$ por 10 minutos, para a evaporação total do "Membrane Wash Solution". 
O DNA foi então eluído transferindo-se a coluna para um microtubo limpo, e adicionando-se $50 \mu \mathrm{L}$ de água ultrapura diretamente no centro da coluna, incubando a amostra por 1 minuto em temperatura ambiente e centrifugando a amostra a $16.000 \mathrm{x}$ $g$ por 1 minuto. Esse procedimento foi realizado para retirar resíduos de sais e produtos não incorporados durante a reação de PCR. A quantificação do produto foi analisada por eletroforese em gel de agarose Invitrogen, USA) a 2\%. A estimativa da concentração de DNA do produto de PCR foi feita com auxílio do reagente Low DNA Mass Ladder (Invitrogen, USA). As intensidades das bandas de DNA purificadas foram comparadas visualmente com os padrões, e a concentração de DNA das amostras em nanogramas foi determinada de acordo com a tabela fornecida pelo fabricante.

O sequenciamento foi realizado na plataforma ABI PRISM® 3500 Genetic Analyzer no Laboratório de Parasitologia do Instituto de Medicina Tropical (IMTUSP). A reação propriamente dita utilizou o kit BigDye® Terminator Cycle Sequencing (Applied Biosystems,USA). Resumidamente, em $10 \mu \mathrm{L}$ de reação contendo Mix BigDye 1:16; 1,5 x o 5 x Sequencing Buffer; foram adicionados $5 \mu \mathrm{M}$ de cada primer. A reação foi realizada em termociclador nas seguintes condições: 25 ciclos de $95^{\circ} \mathrm{C}$ por 10 segundos, $50^{\circ} \mathrm{C}$ por 5 segundos, $60^{\circ} \mathrm{C}$ por 2 minutos. Para a retirada de produtos não incorporados durante a reação de sequenciamento foi realizada a precipitação do DNA utilizando o reagente BigDye ${ }^{\circledR} X$ Terminator $^{T M}$ Purification kit (Applied Biosystems, USA) seguindo as instruções descritas pelo fabricante.

Os eletroferogramas obtidos após sequenciamento foram editados manualmente utilizando o software BioEDIT Sequence Aligment Editor. As sequências foram alinhadas e analisadas no programa Codon Code Aligner. Após edição, as sequências, juntamente com as amostras positivas sequenciadas, foram submetidas à análise comparativa no site BLAST (https://blast.ncbi.nlm.nih.gov/Blast.cgi) para verificar a similaridade entre elas e as sequências "protótipo" de cada um dos microrganismos investigados na multiplexnested-PCR. As sequências protótipo foram obtidas do GenBank (https://www.ncbi.nlm.nih.gov/genbank). 


\subsection{ANÁLISE DOS RESULTADOS.}

Foi calculada a frequência de amostras positivas em relação ao total de amostras analisadas pelos dois testes moleculares por contagem direta. Também foi analisada a frequência de amostras positivas para cada patógeno em relação ao total de amostras estudadas. 


\section{RESULTADOS}

5.1 Grupo de estudo: o grupo de estudo foi composto por 147 gestantes. Destes 147 casos foram colhidas 173 amostras, a saber: 121 amostras de líquido amniótico, 25 amostras de sangue fetal (cordocentese), 4 amostras de sangue de cordão (sala de parto), 7 fragmentos de placenta, 8 amostras de urina de recém-nascidos nas primeiras 72 horas de vida, e 8 amostras de líquido cefalorraquiano de recém-nascidos nas primeiras 72 horas de vida.

Os critérios utilizados para a inclusão de casos no grupo de estudo foram detalhados na Tabela 3.

Tabela 3 - Alterações consideradas para a inclusão de casos no grupo de estudo, número de gestantes incluídas e frequência. $\mathrm{O}$ número total de casos com alterações ultrassonográficas foi de $80(71+1+8)$.

\begin{tabular}{|c|c|}
\hline Critérios de Inclusão & $\begin{array}{l}\text { Número de gestantes } \\
\text { (frequência) }\end{array}$ \\
\hline Apenas alterações ultrassonográficas & $71(48,3 \%)$ \\
\hline Sorologia positiva para algum patógeno & $40(27,2 \%)$ \\
\hline PCR ou imuno-histoquímica positiva em outro laboratório & $26(17,7 \%)$ \\
\hline Alteração ultrassonográfica e óbito fetal & $01(0,7 \%)$ \\
\hline Alteração ultrassonográfica e sorologia positiva & $08(5,4 \%)$ \\
\hline Crescimento intrauterino $<$ percentil 5 & $01(0,7 \%)$ \\
\hline Total de casos & $147(100 \%)$ \\
\hline
\end{tabular}

Para a inclusão de casos no grupo de estudo, a gestante deveria apresentar alterações clínicas e/ ou sorológicas e/ ou ultrassonográficas que levassem à suspeita de infecção congênita. As alterações ultrassonográficas encontradas nas gestantes do grupo de estudo foram detalhadas na Tabela 4. 
Tabela 4 - Alterações ultrassonográficas encontradas nos fetos do grupo de estudo e porcentagem relativa.

\begin{tabular}{|c|c|c|}
\hline Número de alterações & Tipo de alteração & Fetos $(\%)$ \\
\hline \multirow{15}{*}{ Apenas uma alteração } & Hidropsia & $19(23,75 \%)$ \\
\hline & Cardiopatia & $6(7,5 \%)$ \\
\hline & Ascite & $5(6,25 \%)$ \\
\hline & Hidrocefalia & $5(6,25 \%)$ \\
\hline & higroma cístico & $4(5,0 \%)$ \\
\hline & Holoprosencefalia & $2(2,5 \%)$ \\
\hline & Esquizencefalia & $2(2,5 \%)$ \\
\hline & Derrames pericárdicos & $1(1,25 \%)$ \\
\hline & Calcificações intracranianas & $1(1,25 \%)$ \\
\hline & Esplenomegalia & $1(1,25 \%)$ \\
\hline & Anencefalia & $1(1,25 \%)$ \\
\hline & Gânglios cervicais aumentados & $1(1,25 \%)$ \\
\hline & Braquiocefalia & $1(1,25 \%)$ \\
\hline & Spina bífida & $1(1,25 \%)$ \\
\hline & Ventriculomegalia & $1(1,25 \%)$ \\
\hline \multirow{10}{*}{ Duas alterações } & Hidropsia e higroma & $4(5,0 \%)$ \\
\hline & Higroma e edema cutâneo & $1(1,25 \%)$ \\
\hline & Hidropsia e cardiopatia & $1(1,25 \%)$ \\
\hline & Hidropsia e derrame pericárdico & $1(1,25 \%)$ \\
\hline & Hipoplasia ventricular esquerda & $1(1,25 \%)$ \\
\hline & Hidrocefalia e clinodactilia & $1(1,25 \%)$ \\
\hline & Hidrocefalia e agenesia do vermis cerebelar & $1(1,25 \%)$ \\
\hline & Encurtamento dos membros e lesão de coluna & $1(1,25 \%)$ \\
\hline & Pielectasia e osso nasal ausente & $1(1,25 \%)$ \\
\hline & Esplenomegalia e aumento de gânglios cervicais & $1(1,25 \%)$ \\
\hline \multirow{11}{*}{ Três ou mais alterações } & $\begin{array}{l}\text { Hidrocefalia, agenesia do corpo caloso, holoprosencefalia, } \\
\text { aumento dos gânglios cervicais }\end{array}$ & $4(5 \%)$ \\
\hline & Hidropsia, higroma, derrame pleural, edema & $2(2,5 \%)$ \\
\hline & Cardiomegalia, ventriculomegalia, polidrâmnio & $2(2,5 \%)$ \\
\hline & Higroma cístico, onfalocele, hidropsia & $2(2,5 \%)$ \\
\hline & Hidrocefalia, ventriculomegalia e ausência de vermis cerebelar & $1(1,25 \%)$ \\
\hline & Hidrocefalia, calcificações periventriculares e hepatomegalia & $1(1,25 \%)$ \\
\hline & $\begin{array}{l}\text { Ventriculomegalia, calcificações intracranianas, } \\
\text { hepatoesplenomegalia }\end{array}$ & $1(1,25 \%)$ \\
\hline & Cardiomegalia, hidropsia fetal, derrame pericárdico & $1(1,25 \%)$ \\
\hline & Hidropsia, derrame pericárdico, cardiomegalia, derrame pleural & $1(1,25 \%)$ \\
\hline & Holoprosencefalia, fenda palatina, hipotelorismo & $1(1,25 \%)$ \\
\hline & Total & $80(100 \%)$ \\
\hline
\end{tabular}


5.2 Grupo Controle: o grupo controle foi composto por 193 gestantes oriundas de atendimentos de gestantes com pré-natal normal ou primigestas com idade avançada (Tabela 5).

Tabela 5 - Critérios de inclusão das gestantes no grupo controle e porcentagem relativa.

\begin{tabular}{lc}
\hline \multicolumn{1}{c}{ Critérios de inclusão } & Número de gestantes (\%) \\
\hline PN nl, idade avançada (amniocentese - cariotipagem) & $44(22,8 \%)$ \\
PN nl, triagem sorológica nl , placenta nl & $149(77,2 \%)$ \\
\hline Total de casos & $\mathbf{1 9 3 ( 1 0 0 \% )}$
\end{tabular}

PN- Pré-Natal; nl.- normal.

No grupo controle, além das 197 amostras das 193 gestantes (44 líquidos amnióticos e 148 amostras de sangue de cordão colhidos da placenta na sala de parto), três fragmentos de placenta foram encaminhados ao laboratório para análise (o exame histopatológico das placentas foi normal), e em um dos casos houve coleta de duas amostras de sangue da placenta por se tratar de gestação gemelar, totalizando 197 amostras neste grupo.

\subsection{Resultados da multiplex-nested-PCR no grupo de estudo}

Do total de 147 gestantes do grupo de estudo, 57 apresentaram resultado positivo pela multiplex-nested-PCR (38,8\%). Quatro casos dos 147 do grupo de estudo (2,7\%) apresentaram dupla detecção: 2 casos positivos para CMV e Toxoplasma gondii em líquido amniótico; 1 caso positivo para Toxoplasma gondii e VZV em líquido amniótico; 1 caso positivo para parvovírus B19 e CMV em sangue fetal.

Não foram detectados casos de infecção congênita causada por HSV e EBV no grupo de estudo. Os outros cinco patógenos que foram alvo da investigação pela multiplex-nested-PCR foram detectados.

Considerando os resultados por número de amostras colhidas, de um total de 173 amostras foram encontradas 66 positivas $(38,1 \%)$. A Figura 1, mostra o total de amostras $(n=173)$ das 147 gestantes do grupo de estudo, bem como os tipos de material biológico analisados, e a frequência de patógenos detectados por multiplex-nestedPCR. 


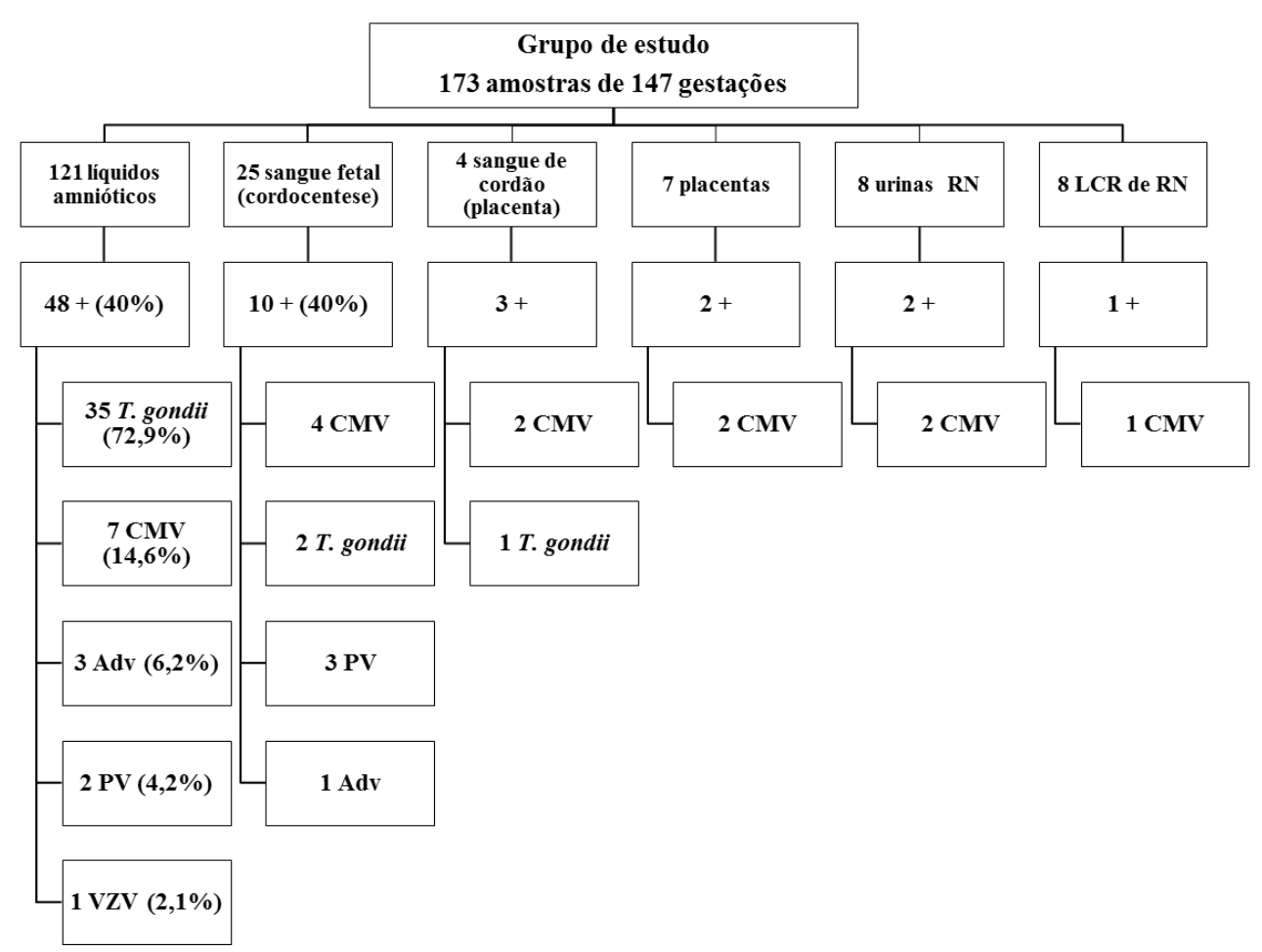

Figura 1 - Número total de amostras do grupo de estudo distribuídos de acordo com o tipo de material analisado, e os patógenos detectados pela técnica de multiplex-nested-PCR, além da porcentagem relativa

Na Tabela 6 foram apresentados todos os 57 casos positivos do grupo de estudo e as respectivas alterações (clínicas e laboratoriais) encontradas. Em alguns casos foi realizada PCR no laboratório de apoio do centro de referência participante do estudo.

Tabela 6 - Descrição do número de casos positivos por multiplex-nested-PCR $(\mathrm{n}=57)$ de acordo com o patógeno, e as respectivas alterações clínicas, laboratoriais e de exames subsidiários.

\begin{tabular}{lcccccc}
\hline \multicolumn{1}{c}{ Critérios de Inclusão } & $\begin{array}{c}\text { T. gondii } \\
\mathbf{N = 3 2}\end{array}$ & $\begin{array}{c}\text { CMV } \\
\text { N=12 }\end{array}$ & $\begin{array}{c}\text { PV } \\
\text { N=5 }\end{array}$ & $\begin{array}{c}\text { Adeno } \\
\text { N=4 }\end{array}$ & $\begin{array}{r}\text { Dupla } \\
\text { detecção } \\
\text { N=4 }\end{array}$ & $\begin{array}{c}\text { Total } \\
\text { N=57 }\end{array}$ \\
\hline Apenas alterações ultrassonográficas & 14 & 4 & 1 & 3 & 2 & 24 \\
Sorologia + & 7 & 3 & 0 & 1 & 0 & 11 \\
PCR ou IH + (lab. apoio) & 3 & 2 & 0 & 0 & 1 & 6 \\
Sorologia + e alteração ultrassonográfica & 0 & 1 & 4 & 0 & 1 & 6 \\
PCR ou IH + e alteração ultrassonográfica & 5 & 2 & 0 & 0 & 0 & 7 \\
PCR ou IH + e sorologia + & 2 & 0 & 0 & 0 & 0 & 2 \\
Crescimento intrauterino < p 5 & 1 & 0 & 0 & 0 & 0 & 1 \\
\hline
\end{tabular}


5.4 Resultados da multiplex-nested-PCR no grupo controle: de um total de 193 casos, foram colhidas 197 amostras. Houve detecção por multiplex-nested-PCR em 2 casos: 1 caso positivo para T. gondii em líquido amniótico e 1 caso positivo para adenovírus em líquido amniótico (2/193 casos ou 1,04\%; 2/197 amostras ou 1,01\%). (Figura 2).

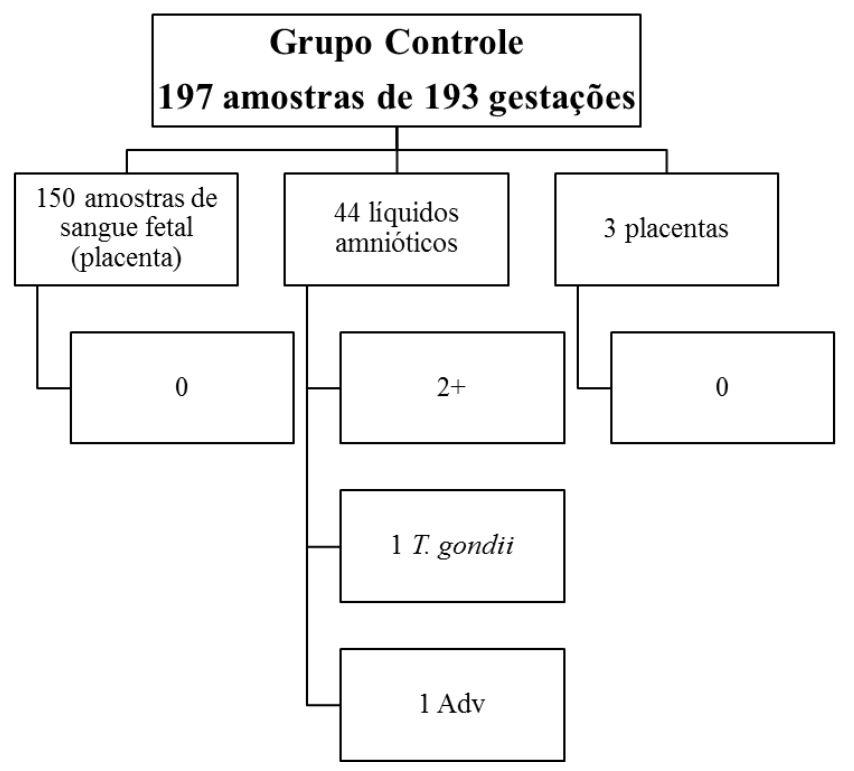

Figura 2 - Amostras biológicas e os patógenos encontrados pela técnica de multiplex-nested-PCR no grupo controle.

Dentre as 193 gestantes do grupo controle, o cariótipo foi anormal em 14 casos $(7,2 \%)$ :

- 2 casos: 69 XXY (cariótipos realizados em líquido amniótico);

- 2 casos: 46 XX, inv. (9) (p12q13) (cariótipos realizados em líquido amniótico);

- 2 casos: 47 XX+13 (cariótipos realizados em líquido amniótico);

- 2 casos: 47 XY+18 (um cariótipo realizado em líquido amniótico e um cariótipo realizado em sangue fetal - gestante com idade avançada);

- 1 caso: 46 XX del. (11) (q22) (cariótipo realizado em líquido amniótico);

- 1 caso: 46 XY, del. (22) (p11.1) (cariótipo realizado em líquido amniótico);

- 1 caso: 45 XX del. $(18,21)+(18,21)(p 11.3 ; p 12)$ (cariótipo realizado em líquido amniótico);

- 1 caso: 45 X (cariótipo realizado em líquido amniótico);

- 1 caso: 45 X, 46 XY (cariótipo realizado em líquido amniótico).

- 1 caso: 47 XX+21 (cariótipo realizado em líquido amniótico) 


\subsection{Resultados do sequenciamento automatizado dos fragmentos detectados pela}

multiplex-nested-PCR

Os amplificados dos 57 casos positivos do grupo foram submetidos ao sequenciamento automatizado para confirmação, e os quatro casos nos quais houve dupla detecção pela multiplex-nested-PCR foram representados a seguir.

Foi realizado alinhamento das sequências obtidas no estudoem relação as sequências protótipo obtidas no GeneBank. As sequências geradas pelo equipamento ABI PRISM® 3500 Genetic Analyzer, analisadas pelo programa BLAST (https://blast.ncbi.nlm.nih.gov/Blast.cgi). Observamos grau similaridade de $95 \%$ e 98\% entre a sequência amplificada do líquido amniótico e os protótipos, confirmando que os amplificados eram mesmo provenientes dos patógenos que esperávamos ter amplificado. 


\section{DISCUSSÃO}

O presente estudo teve como objetivo o desenvolvimento de uma multiplexnested-PCR capaz de detectar de forma simultânea, sete patógenos que contêm DNA no genoma, e que já foram associados a infecções congênitas. Como já foi mencionado, a escolha das infecções que seriam investigadas com a multiplex-nestedPCR foi feita em conjunto com especialistas em Medicina Fetal do HC/FMUSP.

Ao longo da última década, tem havido um aumento no emprego de sistemas do tipo multiplex-PCR para a detecção simultânea de patógenos em vários tipos de material biológico, provavelmente devido à escassez de material para a realização de vários testes, em relação a amostras do trato respiratório ${ }^{50,51}$, gastrointestinal ${ }^{52}$, oculares $^{53}$, provenientes de linfadenopatias ${ }^{54}$, líquido cefalorraquidiano ${ }^{55,56,57}$, dentre outras.

Muito embora uma PCR realizada separadamente para cada um dos patógenos considerados nesta pesquisa, ou o emprego da PCR em Tempo Real pudessem apresentar vantagens em relação à multiplex-nested-PCR, existem razões para a realização de testes combinados, tais como a escassez de material biológico (DNA extraído de amostras de líquido amniótico ou sangue fetal), e o menor custo. A realização de uma dezena de sorologias com plasma/soro fetal também enfrentaria o mesmo obstáculo, isto é, a quantidade insuficiente de amostra.

Durante a etapa de padronização (determinação das melhores condições laboratoriais, concentrações de reagentes, temperaturas de amplificação), e de validação (teste de amostras provenientes de gestantes e fetos com ou sem suspeita de infecção congênita) da multiplex-nested-PCR procuramos utilizar protocolos, equipamentos e condições laboratoriais que pudessem ser reproduzidas em outros laboratórios de biologia molecular. Esta foi a razão para a substituição dos géis de agarose, usados na detecção de amplificados, pela eletroforese capilar. Além de um maior grau de resolução, sendo capaz de diferenciar fragmentos com diferenças de peso molecular de 2 a 4 pares de base, a eletroforese capilar é substancialmente mais rápida que a eletroforese em géis de agarose, apresenta menor custo, e não requer que o manipulador lide com substâncias que se intercalam ao DNA, e são, portanto, cancerígenas, tais como o brometo de etídeo. 
$\mathrm{Na}$ atualidade, existe recomendação para que se empregue amplificações quantitativas (PCR em Tempo Real) quando o objetivo do teste for o diagnóstico laboratorial de doenças infecciosas, sobretudo naquelas que podem ser tratadas, uma vez que a determinação da quantidade de patógenos presentes na amostra pode ser útil tanto para a definição do diagnóstico, quanto para o acompanhamento do tratamento ${ }^{62}$. Mesmo assim, apesar de não constituir a situação ideal para testes que têm como objetivo o diagnóstico laboratorial, a presente pesquisa realizou duas amplificações (nested-PCR) com o intuito de aumentar tanto a sensibilidade, quanto a especificidade da reação. O ganho de sensibilidade é facilmente compreendido pois o material amplificado na $1^{\text {a }}$ PCR foi diluído 100 vezes e 2 microlitros desta diluição foram submetidos a uma nova amplificação ( $\left.2^{\mathrm{a}} \mathrm{PCR}\right)$. $\mathrm{O}$ ganho de especificidade ocorre pois para se obter a amplificação de um determinado fragmento específico de um dos patógenos, é preciso que o DNA alvo presente na amostra do paciente tenha sido reconhecido pelos pares de primers da $1^{\mathrm{a}}$ e da $2^{\mathrm{a}}$ amplificação.

A situação ideal seria a de se poder realizar, em lugar da multiplex-nested-PCR, uma PCR em Tempo Real que pudesse detectar os 7 patógenos de forma simultânea. A PCR em Tempo Real poderia, teoricamente, apresentar sensibilidade analítica (limite de detecção) comparável a uma amplificação dupla (nested-PCR), porém, teria que ser realizada com 14 primers marcados ou não com fluoróforos, além de 7 sondas obrigatoriamente marcadas com fluoróforos distintos. O uso de um grande número de fluoróforos aumentaria demasiadamente o custo da reação, tornando-o proibitivo para a definição do diagnóstico laboratorial de infecções congênitas. Ademais, os fluoróforos possuem prazo de validade, de cerca de um ano (em geral seis meses após a chegada ao laboratório), enquanto os reagentes da PCR convencional apresentam prazo de validade mais longo. Após esta reflexão, e considerando que para a confirmação dos resultados encontrados foram realizados os sequenciamentos de todos os produtos de amplificação obtidos, uma vez que o sequenciamento de DNA constitui o padrão ouro para a análise de sequências de DNA em biologia molecular, para a próxima etapa de implantação da multiplex-nested-PCR que foi padronizada e validada no âmbito desta tese de doutorado, pretende-se adotar a realização da PCR em Tempo Real com SYBR Green para a amplificação, em separado, apenas do patógeno detectado inicialmente pela multiplex-nested-PCR, em substituição ao 
sequenciamento. Este procedimento deverá apresentar sensibilidade comparável àquela da multiplex-nested-PCR, uma vez que não estarão presentes os outros 12 primers na reação, e na PCR em Tempo Real existe hibridização do fluoróforo SYBR Green a cada fragmento amplificado, e esta hibridização aumenta a sensibilidade da técnica. A PCR em Tempo Real realizada com SYBR Green possui, atualmente, um custo aceitável para que possa ser empregada como teste confirmatório, e certamente muito mais baixo que o sequenciamento automatizado (método de Sanger). Ademais, possui a inegável vantagem de quantificar o alvo da amplificação, situação desejável no caso de infecções que podem ser tratadas, tais como a toxoplasmose, podendo a técnica ser igualmente empregada para o monitoramento do tratamento, se houver indicação médica ${ }^{58}$.

$\mathrm{Na}$ presente pesquisa, todos os resultados positivos foram confirmados por meio do sequenciamento do material amplificado (Figuras 11 a 17), desta forma, é possível afirmar que as sequências amplificadas correspondem aos patógenos identificados pela multiplex-nested-PCR. É importante lembrar que apenas 10 dos 57 casos positivos $(17,5 \%)$ foram diagnosticados pelos métodos disponíveis nos laboratórios de apoio dos centros de referência que participaram do estudo, quantidade quase seis vezes menor de casos positivos detectados em relação ao que foi obtido pela multiplex-nested-PCR. Estes 10 casos tiveram sorologias realizadas, em alguns deles também havia resultados de PCR in house dos laboratórios de apoio dos serviços de obstetrícia, além de resultados de outros exames subsidiários indicativos de infecção (imunoistoquímica, imagem etc). Ressaltamos que os estudos da literatura que foram citados na parte introdutória da tese realizaram apenas a investigação molecular, sem preocupação com a existência de testes confirmatórios para confirmar os resultados obtidos por PCR, com exceção do relato de McIver et $\mathrm{al}^{44}$.

Com relação a possibilidade de termos obtido resultados falso-positivos pela multiplex-nested-PCR, foram adotadas medidas para minimizar a chance de contaminação laboratorial (carry-over), tais como a compartimentalização de áreas de preparo de reagentes, extração de DNA e amplificação, seguindo recomendações da literatura ${ }^{59}$. Em algumas situações, a multiplex foi positiva, por exemplo para T. gondii ou CMV, e as sorologias maternas indicavam presença de IgG positiva e IgM negativa para o patógeno detectado na PCR. No entanto, é importante lembrar que as sorologias 
analisadas foram maternas e não fetais, sendo plausível que a infecção já se encontrasse em fase sub-aguda ou crônica na gestante (perfil de infecção pregressa) e em fase aguda no feto, culminando com o resultado positivo por PCR. Por este motivo existe recomendação, por exemplo, no caso de suspeita de infecção congênita pelo CMV, que se aguarde período de 7-9 semanas após a infecção aguda materna para a realização da investigação fetal, devendo a amniocentese ser realizada de preferência após a $21^{\mathrm{a}}$ semana de gestação ${ }^{60}$.

Do total de 57 casos positivos encontrados no grupo de estudo, o patógeno mais frequentemente amplificado foi $T$. gondii, em 32 casos dos 57 positivos $(56,1 \%)$ e em $21,8 \%$ do total de 147 casos do grupo de estudo. Esta porcentagem é bastante elevada, porém não existem trabalhos na literatura para podermos comparar os dados. É possível que os dois centros obstétricos que participaram desta pesquisa concentrem mais casos verdadeiros de infecção congênita.

$\mathrm{Na}$ presente pesquisa não foram detectados casos de infecção congênita causada por HSV e EBV, mas estas duas infecções parecem mesmo ser menos frequentes $^{25,10,15}$.

Dos 32 casos com multiplex-nested-PCR positiva para T. gondii desta casuística, todos possuíam ao menos um (a maioria dos casos mais de um) critério de inclusão para serem incluídos no grupo de estudo. Chamou-nos a atenção o fato de, dentre os 32 casos detectados, cinco apresentarem PCR para T. gondii negativa realizada no laboratório de apoio, porém o teste molecular naquele laboratório foi uma PCR convencional com apenas um round de amplificação, que costuma ser menos sensível que as nested-PCR, especialmente se levarmos em consideração que as gestantes iniciaram o tratamento assim que o resultado das sorologias foi disponibilizado. O tratamento, é considerado capaz de interromper a replicação dos parasitos, mas não promover a eliminação dos mesmos. Na lista casos positivos para T. gondii, existem apenas cinco casos que foram positivos pela PCR convencional do laboratório de apoio, porém não é possível estimar a sensibilidade e especificidade do teste molecular de outros laboratórios. Ademais, de acordo com dados dos prontuários médicos, a PCR não foi solicitada em todos os 32 casos positivos pela multiplexnested-PCR desta pesquisa, por vezes falta de disponibilidade da PCR, pela presença 
de sorologia anti-T. gondii com IgM positiva associada a alterações ultrassonográficas indicativas da infecção, dentre outros fatores.

Analisando detalhadamente as alterações ultrassonográficas encontradas nos 32 casos positivos para toxoplasmose do grupo de estudo, além de alterações reconhecidamente associadas a infecções tais como vários casos de hidrocefalia fetal, alguns de hidropsia fetal e um caso de crescimento intrauterino restrito abaixo do percentil 5, pudemos observar alterações normalmente associadas a outras infecções (lesão de coluna sacral e encurtamento de membros), e muitas alterações cardíacas, mais frequentemente associadas a outras infecções congênitas tais como a rubéola, tanto anomalias estruturais (hipoplasia de ventrículo esquerdo, cardiopatia fetal não especificada, malformação cardíaca não especificada), quanto funcionais (cardiomegalia fetal, derrame pericárdico). Chamou-nos a atenção a presença de inúmeros casos de malformação de sistema nervoso central (agenesia de corpo caloso, hipoplasia de cerebelo, holoprosencefalia). Muito embora a literatura médica aponte uma baixa prevalência de anomalias do sistema nervoso central fetal, Kilic e Yazici ${ }^{61}$ relataram o caso de um feto com holoprosencefalia, cebocefalia, coloboma em íris esquerda, hipotelorismo, narina única e alterações cardíacas (forame oval patente e septo inter-atrial) associados a infecção fetal. A sorologias indicavam a presença de anticorpos $\mathrm{IgG}$ em títulos altos (IgM negativa) para CMV, HSV e vírus da rubéola, este último vírus reconhecido há muitas décadas como um agente viral teratogênico ${ }^{62}$. Mais recentemente, de Catte et al. ${ }^{63}$ realizaram uma revisão sistemática com especial atenção a malformações de sistema nervoso central detectadas durante o pré-natal. Concluíram que várias alterações tais como a microcefalia estão intimamente relacionadas a infecções causadas por CMV, porém alterações mais graves como agenesia de vernix, holoprosencefalia e outras malformações de linha média, também deveriam ter múltiplas causas infecciosas investigadas, tal como foi realizado na presente pesquisa.

Se considerarmos as estatísticas mundiais, T. gondii deveria ser o segundo agente etiológico mais frequente, porém, CMV foi o segundo colocado com 12 casos ( $21 \%$ dos positivos e $8,2 \%$ do total do grupo). Em apenas um dos 12 casos com multiplex-nested-PCR positiva para CMV a indicação da amniocentese não ficou clara, uma vez que a gestante apresentava apenas sorologia positiva (somente $\operatorname{IgG}$ ) 
para T. gondii, e na época, a sorologia para CMV não era solicitada no rastreamento pré-natal. No prontuário desta gestante não foram encontrados outros critérios de inclusão para o grupo de estudo.

O encontro de $21 \%$ de casos positivos por multiplex-nested-PCR para CMV deveria ser ainda mais elevado, e a redução da detecção de CMV como agente etiológico de infecções congênitas em nosso meio deve estar associada ao fato do CMV não ter feito parte do rastreamento sorológico rotineiramente realizado no atendimento pré-natal de todos os centros obstétricos, desde o início da realização desta pesquisa. Um fator de confusão que permanece no diagnóstico pré-natal da infecção congênita causada pelo CMV é a idade gestacional na qual a amniocentese ou a cordocentese é realizada. Após a primo-infecção materna, pode levar semanas a meses para que a transmissão placentária do CMV ocorra. Um intervalo de 7-9 semanas entre o início da infecção materna e a realização do teste diagnóstico tem sido recomendado. A idade gestacional no momento do teste também constitui fator importante, uma vez que a sensibilidade da PCR pode ser de apenas 30\% quando a amostra de líquido amniótico é obtida antes da $21^{\mathrm{a}}$ semana de gestação, podendo atingir $100 \%$ se o teste for realizado após a $21^{a}$ semana $^{60}$. No presente estudo, todas as amniocenteses foram realizadas no segundo trimestre da gestação, porém várias delas antes da $18^{\mathrm{a}}$ semana, que é a idade gestacional recomendada para a pesquisa de $T$. gondii em líquido amniótico ${ }^{15}$ e uma quantidade ainda maior antes da $21^{\text {a }}$ semana, idade gestacional recomendada para a detecção molecular do CMV, muito embora, de uma forma geral, o procedimento tenha sido realizado sempre após quatro semanas ou mais da data provável de soroconversão.

No grupo de estudo, foram encontrados cinco casos com detecção de parvovírus B19. Todos os fetos apresentavam alterações ultrassonográficas significativas: 1 feto hidrópico; 1 feto com ventriculomegalia; 1 feto com hidrocefalia, ventriculomegalia e ausência de vermis cerebelar; 2 fetos com esquizencefalia. Ademais, considerando os resultados de PCR realizada nos laboratórios de apoio, a PCR foi positiva em um dos casos, portanto apenas este caso teria sido diagnosticado, porém a PCR foi negativa em um dos casos positivos pela multiplex-nested-PCR deste estudo, correspondendo, provavelmente a um falso-negativo do laboratório de apoio, provavelmente pelo uso de PCR convencional com um único round de amplificação. 
Ademais, houve um caso com sorologia inconclusiva e no último dos cinco casos a sorologia foi negativa. Nestes dois últimos casos, a PCR não foi realizada nos laboratórios de apoio. Considerando a presença de alterações ultrassonográficas fetais graves em todos os cinco casos com multiplex-nested-PCR positiva, acreditamos que esta técnica seja mais sensível que as sorologias e as PCR in house convencionais.

Ainda no grupo de estudo, foram encontrados quatro casos positivos para adenovírus pela multiplex-nested-PCR. Os quatro casos apresentavam as seguintes alterações que os tornavam elegíveis: cardiopatia fetal; hidrocefalia grave; higroma cístico e edema subcutâneo fetal; sorologia positiva para CMV. Os adenovírus são frequentemente associados a casos de hidropsia fetal, mas nesta casuística apenas o feto com edema subcutâneo talvez pudesse apresentar um certo grau de hidropsia. No entanto, cardiopatias fetais (arritmias, insuficiência cardíaca) e malformações cardíacas fetais que já foram associadas aos adenovírus, assim como lesões hepáticas ecogênicas e defeitos do tubo neural, dentre outras alterações do sistema nervoso central, não foram encontradas nestes quatro casos positivos para adenovírus ${ }^{34,36,37,38}$. Apenas o caso com sorologia positiva para CMV (detecção de IgM em títulos baixos e IgG), sem outras alterações mencionadas em prontuário, carece ainda de explicações. Pudemos constatar que, a partir de um determinado momento durante a realização da pesquisa, a sorologia para CMV passou a integrar o painel sorológico do rastreamento pré-natal de um dos centros. Infelizmente, a sorologia para adenovírus não é realizada rotineiramente na maior parte dos centros de atendimento obstétrico, mesmo naqueles localizados em hospitais de referência. Sendo assim, não temos um outro exame laboratorial para avaliar os resultados da multiplex-nested-PCR que foram positivos para adenovírus.

No grupo de estudo (gestações com suspeita de infecção congênita) foram encontrados quatro casos nos quais houve dupla amplificação pela multiplex-nestedPCR, sendo dois casos com detecção de T. gondii e CMV em líquido amniótico; um caso com detecção de T. gondii e VZV em líquido amniótico; um caso com detecção de parvovírus B19 e CMV em sangue fetal. Estes quatro casos corresponderam a $2,72 \%$ do total de147 casos) e a 2,3\% do total de 173 amostras. Havia dois casos com dupla detecção de T. gondii e CMV. Em um deles, foram solicitadas sorologias maternas para $T$. gondii e CMV, ambas com IgG positiva e IgM negativa, porém o feto 
se encontrava hidrópico e havia um teste imuno-histoquímico positivo para CMV em líquido amniótico. No outro caso com dupla identificação $T$. gondii e CMV, a gestante apresentava IgG e IgM positiva para $T$. gondii. Um terceiro caso apresentou dupla detecção $T$. gondii e VZV e a gestante apresentava IgG e IgM positiva para $T$. gondii, não tendo sido realizada sorologia para VZV. O último dos quatro casos com dupla identificação detectou CMV e parvovírus B19. O feto se encontrava hidrópico (compatível com os dois agentes virais), e havia PCR positiva para parvovírus B19 do laboratório de apoio. Infelizmente neste caso, não foi solicitada sorologia para CMV.

Analisando estes quatro casos com dupla detecção de patógenos de outra maneira, é possível observar que todos eles apresentaram detecção de algum microrganismo (T. gondii ou parvovírus B19) juntamente com um vírus da família herpes (em três casos o CMV e em um caso o VZV). É possível que os fetos apresentassem a infecção por um dos patógenos ( $T$. gondii ou parvovírus), e o vírus da família herpes estivesse presente, portanto passível de detecção, porém sob forma "latente". Sabe-se que os vírus da família herpes desenvolveram interações vírushospedeiro muito particulares, sendo capazes de sofrer adaptações e trilhar uma série de caminhos para escapar da vigilância imunológica do hospedeiro. Os mecanismos que permitem a persistência dos vírus da família herpes no organismo são muito complexos. Dependendo do estado de competência imunológica do indivíduo e dos tipos de células infectadas, a persistência dos herpes vírus compreenderá estados de latência, cronicidade e estados produtivos de infecção, que podem ocorrer concomitantemente. A latência viral é uma estratégia central pela qual os herpes vírus garantem a sua persistência ao longo da vida do hospedeiro. Embora ainda haja muito a ser definido sobre as interações vírus-hospedeiro importantes para a latência do CMV, e de outros herpes vírus, a existência de fatores virais e celulares para a manutenção de um estado latente ou para dar início a replicação produtiva do vírus em resposta a estímulos do hospedeiro já foi exaustivamente documentada $64,65,66,67,68,69$.

Uma forma para contornar o problema de detecções por PCR que corresponderiam a agentes virais latentes no organismo do paciente, seria a detecção realizada por multiplex-RT-nested-PCR, ou seja, em lugar de se extrair DNA, haveria extração de RNA, realização de etapa suplementar de transcrição reversa, com produção de DNA complementar (cDNA) e posterior realização de dois rounds de 
amplificação. Esta estratégia reduziria a sensibilidade das detecções considerando que a detecção de cDNA é menos sensível que a de DNA, porém apresentaria a vantagem de só haver amplificação caso o(s) patógeno(s) estivesse(m) produzindo RNA mensageiros, isto é, estivessem realizando transcrições, fato que indicaria atividade do agente etiológico. Esta é uma alternativa a ser considerada, porém a inclusão da etapa de transcrição reversa aumentaria a complexidade e o custo da reação, e seria necessário aumentar a organização e a agilidade de todos os processos laboratoriais, notadamente do transporte de materiais biológicos ao laboratório, pois eles teriam que ser processados em tempo não superior a duas horas após a coleta, sob pena de obtermos resultados falso-negativos devido à degradação do RNA presente nas amostras.

Existe, na literatura médica, apenas um estudo recente que detectou mais de um vírus da família herpes de forma simultânea por meio de multiplex PCR, em gestantes. Ouedraogo et al. ${ }^{70}$ realizaram estudo para a detecção de herpes vírus que pudessem estar envolvidos em infecções congênitas, a saber: EBV, CMV e HHV6, e para tanto analisaram 200 gestantes, sendo $100 \mathrm{HIV}$ positivas e $100 \mathrm{HIV}$ negativas. Foram testadas amostras de plasma destas 200 gestantes por multiplex PCR, porém PCR em Tempo Real. Das 200 amostras testadas, 18 (9,0\%) foram positivas para ao menos um dos três patógenos; $12(6,0 \%)$ foram positivas para EBV; $13(6,5 \%)$ foram positivas para CMV, e 12 (6,0\%) foram positivas para HHV6. Dentre os 18 casos com infecção, 10 (55,6\%) apresentavam co-infecção, das quais 9/10 (90\%) tiveram tripla detecção EBV/CMV/HHV6, enquanto 10\% tiveram dupla detecção EBV/HHV6. Surpreendentemente, a detecção de herpes vírus foi mais frequente entre gestantes HIV negativas em relação as HIV positivas (12,0\% versus 6,0\%). Entre gestantes HIV positivas, a PCR foi positiva em 7,1\% (6/85) de gestantes que não recebiam tratamento antirretroviral, não tendo sido encontrada nenhuma gestante positiva dentre as que recebiam tratamento antirretroviral. Os autores concluíram que infecções causadas por herpes vírus são frequentes em gestantes de Burkina Faso e podem representar uma ameaça real à gestação, podendo estar associadas a complicações obstétricas, além de representarem risco de infecção aos fetos. Este estudo também encontrou vários casos com amplificações duplas e triplas, sobretudo em gestantes HIV negativas, sendo todos os patógenos vírus pertencentes a família herpes, há muito tempo reconhecidos 
como microrganismos que podem permanecer no organismo após um primeiro episódio infeccioso.

Foi possível localizar um outro estudo de Rasti et al. ${ }^{71}$, que estudaram o impacto de co-infecções do grupo TORCH no desfecho de gestações, e para tanto, determinaram as concentrações de anticorpos $\operatorname{IgM}$ e $\operatorname{IgG}$ anti-T. gondii, vírus da rubéola, CMV e HSV. Oitenta e uma gestantes que haviam sofrido aborto e 98 gestantes que tiveram parto normal (grupo controle) foram incluídas na pesquisa. Considerando a positividade para apenas uma infecção, somente a detecção de $\operatorname{IgM}$ anti-CMV se encontrava significativamente mais elevada no grupo que sofreu abortos em relação ao grupo controle $(25,9 \%$ versus $12,2 \%, \mathrm{OR}=2,5$ e p= 0,019$)$. No modelo de co-infecção, 14 padrões diferentes foram reconhecidos, porém apenas dois destes padrões apresentaram significância estatística: a co-infecção (dupla) T. gondii (IgG) e CMV (IgM) foi 9,1 vezes mais elevada no grupo que sofreu abortamentos em relação ao grupo controle $(8,6 \%$ versus $1 \%, \mathrm{OR}=9,1 ; \mathrm{p}=0,024)$; e a co-infecção (tripla) $T$. gondii (IgG) + HSV IgG + CMV (IgM) foi 7,7 vezes maior no grupo que sofreu abortos em relação ao grupo controle $(7,4 \%$ versus $1 \%, \mathrm{OR}=7,7 ; \mathrm{p}=0,04)$. Estes resultados, apesar de não tratarem apenas de infecções agudas (detecção de $\operatorname{IgM}$ ), mas também da associação de infecção aguda e infecção (ou infecções) pregressas, com detecção de IgG, indicam que co-infecções maternas do grupo TORCH estão associadas a risco aumentado de abortos em relação a infecções únicas, sugerindo uma possível associação de uma infecção aguda e uma ou várias infecções crônicas na fisiopatologia de abortos. Desta forma, as taxas de co-infecção deveriam ser consideradas na triagem pré-natal das infecções TORCH.

A existência de células fetais em sangue materno já foi devidamente comprovada, e esta característica tem sido utilizada, por exemplo, para a determinação do sexo do feto e a pesquisa de doenças genéticas fetais ${ }^{72,73,74}$. Sabe-se que em casos de filhos de mães HIV positivas, existe passagem placentária de anticorpos de classe IgG e estes anticorpos maternos podem ser detectados na criança por muitos meses ${ }^{75,76}$. No entanto, não é possível afirmar que algum dos patógenos detectados em líquido amniótico ou em sangue fetal no presente estudo estivessem presentes em sangue materno e não no fluido biológico fetal, a não ser que tenham ocorrido acidentes de punção, com passagem de sangue materno para o líquido amniótico, o que não parece 
ter acontecido, pois não foi percebido na recepção das amostras no laboratório. Finalmente, é possível aventar que, não apenas os herpes vírus, mas também adenovírus, parvovírus B19 e até mesmo o parasito T. gondii oriundos de uma infecção materna pregressa, possam voltar a apresentar replicação na gestante, considerando que a gestação representa um estado de imunotolerância, com predomínio de mecanismos Th2 (anti-inflamatórios) em relação aos Th1 (pró-inflamatórios). A gestação é considerada um estado de imunotolerância, por alguns autores até mesmo de imunossupressão, com predomínio da produção de citocinas T helper 2 (Th2) em relação a Th1. Sendo assim, é necessário o predomínio de citocinas Th2 para a manutenção da gestação, e se houver predomínio Th1 poderá ocorrer aborto ou nascimento prematuro ${ }^{77}$.

O grupo controle da presente pesquisa contou com 193 casos e 197 amostras. Foram encontrados 14 cariótipos fetais anormais, como já era esperado $(7,2 \%)$. Houve, neste grupo controle, a detecção por multiplex-nested-PCR em 2 casos: 1 caso positivo para adenovírus em líquido amniótico e 1 caso positivo para T. gondii em líquido amniótico, ou seja, 1,04\% dos casos e 1,01\% se considerarmos o total de amostras. Os adenovírus têm sido os agentes virais mais identificados em gestações com desfecho normal. Infelizmente, não encontramos nenhum estudo que tenha investigado $T$. gondii em gestações com pré-natal normal e desfecho normal, muito embora se saiba que cerca de $80 \%$ das toxoplasmoses congênitas sejam assintomáticas ${ }^{15}$.

Baschat et al. ${ }^{41}$ e Reddy et al. ${ }^{42}$ pesquisaram a presença de genomas virais em gestações normais, e fetos com cariótipos normais. No estudo de Baschat et al. ${ }^{41}, 686$ amostras de líquido amniótico colhidas no segundo trimestre foram avaliadas por multiplex-PCR para a detecção de CMV, HSV, EBV, parvovírus B19, adenovírus, além de alguns RNA vírus (enterovírus e vírus sincicial respiratório). Os autores encontraram 44 amostras positivas $(6,4 \%)$. Em 41 destas 44 amostras $(93,2 \%)$ apenas um vírus foi detectado, e em três casos dois vírus foram detectados. Os adenovírus foram os mais frequentes (37/44 ou 84,1\%), seguidos do CMV (5 casos), EBV (2 casos), enterovírus (2 casos) e sincicial respiratório (1 caso). Parvovírus B19 e HSV não foram encontrados nesta casuística. Em 2005, Reddy et al. ${ }^{42}$ verificaram se a detecção de genomas virais em amostras de líquido amniótico estaria associada a gestações com desfecho anormal. CMV, HSV, EBV, parvovírus B19, adenovírus, 
além de alguns RNA vírus, tais como os enterovírus e o vírus sincicial respiratório foram investigados por PCR em 423 amostras de líquido amniótico, sendo que 57 amostras (13,5\%) foram positivas: adenovírus (78\%), enterovírus (12\%), CMV (5\%) e parvovírus B19 (5\%). Dos casos com ultrassom fetal anormal, 24\% tiveram PCR positiva, comparados a $8,4 \%$ das gestações com ultrassom normal. Analisando os estudos de Baschat et al. ${ }^{41}$ e Reddy et al. ${ }^{42}$ é possível verificar uma frequência de resultados de PCR positiva para vírus em $6,4 \%$ e $8,4 \%$ dos casos analisados, enquanto a porcentagem encontrada na presente pesquisa foi mais baixa, de 1,04\%. No entanto, no estudo de McLean et al. ${ }^{39}$, 277 amostras de líquido amniótico foram analisadas por PCR para a detecção de adenovírus, CMV, HSV e parvovírus B19, e nenhum caso positivo foi encontrado. Desta forma, a porcentagem encontrada no presente estudo se encontra em faixa intermediária se considerarmos os três estudos ora descritos.

Dentre os casos do grupo controle tivemos uma amplificação positiva para adenovírus em gestante com idade avançada, tendo sido indicada a amniocentese para a realização do cariótipo, que foi normal. Esta gestante não apresentava outras alterações, a triagem sorológica do pré-natal não era indicativa de infecção, porém, a sorologia para adenovírus não é realizada rotineiramente. Além disso, existem estudos associando o encontro de adenovírus por PCR a gestações com desfecho normal, como parece ter acontecido neste caso $^{41,42}$.

A outra gestante que teve multiplex-nested-PCR positiva no grupo controle também realizou amniocentese devido à idade avançada, para realização do cariótipo. A ultrassonografia fetal mostrou aumento da translucência nucal, alteração raramente associada a feto com cariótipo normal ${ }^{78}$. De fato, o cariótipo fetal revelou trissomia do cromossomo 21 (síndrome de Down) e a multiplex-nested-PCR amplificou DNA de T. gondii. Este não é o primeiro caso na literatura associando toxoplasmose congênita à síndrome de Down. Yamakawa et al. ${ }^{79}$ relataram o caso de um lactente apresentando uma apresentação clínica bastante atípica associando síndrome de Down, toxoplasmose congênita e diabetes insipidus. Hidrocefalia fetal foi detectada na ultrassonografia realizada na $36^{\mathrm{a}}$ semana de gestação. O parto foi prematuro, o recémnascido apresentava baixo peso ao nascimento, além rash cutâneo, petéquias em face e características clínicas compatíveis com síndrome de Down. O recém-nascido desenvolveu diabetes insipidus, seguido de pneumonia intersticial, anemia e 
hepatoesplenomegalia. Com 37 dias de apresentava sorologia com IgM negativo antiT. gondii, porém o líquido cefalorraquidiano colhido no mesmo dia foi positivo por PCR (detecção do gene SAG1 de T. gondii). Este foi o primeiro caso associando a síndrome de Down à toxoplasmose congênita.

Em 1979, Il'inskikh et al. ${ }^{80}$ discutiram o papel de $T$. gondii na gênese de doenças cromossômicas em seres humanos e em animais. Laziuk et al. ${ }^{81}$ já haviam relacionado a toxoplasmose congênita a um outro caso de trissomia, desta vez a do cromossomo 13 (síndrome de Patau), e Von Graefes ${ }^{82}$ em um estudo ainda mais antigo, levantou a hipótese do Toxoplasma gondii poder atuar como agente mutagênico. Mais recentemente, Morava et al. ${ }^{83}$ descreveram o caso de feto portador de mosaicismo e trissomia do cromossomo 8 em gestante que contraiu toxoplasmose na gestação. Também é digno de nota o fato de existirem, neste momento, mais de 150 publicações médicas associando principalmente casos de toxoplasmose congênita, mas também de toxoplasmose adquirida na infância e menos frequentemente em idade adulta a doenças mentais, sobretudo a esquizofrenia ${ }^{84}$.

Com relação ao aumento da translucência nucal, Maymon et al. ${ }^{78}$ relataram que o número de fetos com translucência nucal aumentada e cariótipo normal é pequeno. Nestes casos, é imperativo que se pesquise malformações fetais por meio de ultrassonografia morfológica fetal de alta resolução associada a ecocardiografia fetal. Mais recentemente, Goetzl ${ }^{85}$ analisou outras condições associadas a fetos com translucência nucal aumentada, e encontrou um número aumentado de abortos, óbitos fetais, crescimento intrauterino restrito < percentil 5, malformações cardíacas fetais, pré-eclâmpsia, parto prematuro, natimortos e casos de infecção congênita, especialmente as causadas por parvovírus, CMV e $T$. gondii, geralmente associados a hidropsia fetal. 


\section{CONCLUSÕES}

No presente estudo foi possível padronizar um sistema de detecção molecular do tipo multiplex-nested-PCR para a detecção simultânea de sete patógenos que possuem DNA no genoma, a saber: CMV, HSV, VZV, EBV, parvovírus B19, adenovírus e Toxoplasma gondii.

O teste de casos suspeitos de infecção congênita e casos controle nos permitiu validar a multiplex-nested-PCR, tendo sido os produtos de amplificação submetidos a sequenciamento automatizado, com confirmação do patógeno identificado na multiplex-nested-PCR.

Foram detectados 57 casos positivos no grupo de estudo (38,8\%), e a análise dos prontuários revelou que a multiplex-nested-PCR seria capaz de identificar número quase seis vezes maior de casos de infecção congênita, em relação aos testes rotineiramente realizados nos dois centros de referência que participaram do estudo. Foi encontrada maior frequência relativa de $T$. gondii, seguida de CMV. O encontro de menos casos de CMV em relação aos dados da literatura deve estar relacionado ao fato da sorologia para CMV não fazer parte do rastreamento sorológico de todos os centros obstétricos. No grupo controle foram detectados dois casos positivos $(1,03 \%)$, porcentagem relativamente baixa, tendo sido um dos casos positivo para adenovírus em feto com cariótipo normal, e o outro caso positivo para $T$. gondii, em feto com síndrome de Down. 


\section{PERSPECTIVAS}

Devido à impossibilidade de se diagnosticar infecções congênitas com base apenas em dados clínicos, laboratoriais, ultrassonográficos e sorológicos, uma vez que haveria necessidade de se realizar um número enorme de sorologias, algumas delas não disponíveis mesmo em centros de atendimento terciário da cidade de São Paulo, a realização de uma multiplex-nested-PCR capaz de detectar muitos microrganismos em um único teste constituiria a solução de melhor custo-efetividade para se chegar ao diagnóstico, além de propiciar muitas amplificações com pequena quantidade de DNA/ RNA, considerando que a extração de ácidos nucleicos a partir de amostras de líquido amniótico possui rendimento muito baixo. Pretendemos a seguir implantar sete amplificações em tempo real, correspondendo a cada um dos sete patógenos que fizeram parte desta pesquisa, para substituir os sequenciamentos automatizados dos produtos amplificados pela multiplex-nested-PCR. Desta forma ganharemos tempo e haverá redução de custo, com manutenção do nível de sensibilidade. Desta forma o teste estará pronto para ser implantado na rotina diagnóstica.

Além disso, pretendemos padronizar uma outra multiplex-nested-RT-PCR para a detecção de RNA vírus: rubéola, caxumba, enterovírus (enterovírus propriamente ditos, poliovírus, echovírus e coxsackie vírus) e arbovírus (dengue, chikungunya e zika vírus). O zika vírus foi recentemente associado a fetos e recém-nascidos com microcefalia, sendo possível detectá-lo por RT-PCR em líquido amniótico, assim como em amostras de recém-nascidos (sangue, soro e líquido cefalorraquidiano). 


\section{REFERÊNCIAS BIBLIOGRÁFICAS}

1. Organização Pan-Americana da Saúde. Organização Mundial da Saúde; $47^{\circ}$ Conselho Diretor da Organização Pan-Americana da Saúde. Saúde neonatal no contexto da saúde materna, neonatal e da criança para o cumprimento das metas de desenvolvimento do milênio da declaração do milênio das Nações Unidas. Brasília: Organização Pan-Americana da Saúde, Organização Mundial da Saúde; 2006.

2. Lawn JE, Wilczynska-Ketende K, Cousens SN. Estimating the causes of 4 million neonatal deaths in the year 2000 Int J Epidemiol. 2006 June;35(3):706-18.

3. Mathews TJ, MacDorman MF. Infant mortality statistics from the 2004 period linked birth/infant death data set. Nat Vital Stat Rep. 2007 May 2; 55(14).

4. Fundo das Nações Unidas para a Infância. Situação Mundial da Infância. Capítulo 1: Saúde materna e neonatal: como estamos? [ citado em 2016 Dez 01] Disponível em http://www.unicef.org/brazil/sowc9pt/cap1.htm.

5. EVIPNet - Evidence-Informed Policy Network Mortalidade Perinatal - fetal e neonatal precoce. [ citado em 2016 Dez 01]. http://brasil.evipnet.org/wpcontent/uploads/2010/11/policyBriefs_20101117.pdf.

6. Sociedade Brasileira de Pediatria. Departamento de Neonatologia. Estimativa da Necessidade de Leitos de UTI Neonatal. Relação do número de leitos de UTI Neonatal por 1000 nascidos vivos, 08 de Maio de 2012. [ citado 2016 Dez 01] Disponível em: http://www.sbp.com.br/src/uploads/2015/02/numero_leitos_uti.pdf.

7. Lansky S, Friche AAL, Silva AAM, Campos D, Bittencourt SDA, Carvalho ML, et al. Pesquisa Nascer no Brasil: perfil da mortalidade neonatal e avaliação da assistência à gestante e ao recém-nascido. Mortalidade Neonatal e Avaliação da Assistência Materno-infantil. Cad Saúde Pública.2014;30 Sup:S192-207.

8. Silva AAM, Leite AJM, Lamy ZC, Moreira MEL, Gurgel RQ, Cunha AJLA et al. Morbidade neonatal near miss na pesquisa Nascer no Brasil. Cad. Saúde Pública 2014;.30(1) Sup:S182-91.

9. Nahmias AJ, Walls KW, Steward J, Herrmann KL Flynt WF Jr. The ToRCH complex- perinatal infections associated with toxoplasma and rubella, cytomegaloand herpes simplex viruses. Pediatr Res. 1971;5:405-6. 
10. Jong EP, Vossen,ACTM, Walther FJ, Lopriore E How to use...neonatal TORCH testing. Arch Dis Child Educ Pract Ed. 2013;98:93-8.

11. Musso D, Gubler DJ. Zika Virus. Clin Microbiol Rev. 2016 Jul;29(3):487-524.

12. Tan TG, Mui E, Cong H, Witola WH, Montpetit A, Muench SP, et al. Identification of $T$. gondii epitopes, adjuvants, and host genetic factors that influence protection of mice and humans. Vaccine. 2010;28:3977-89.

13. Shimokawa PT, Targa LS, Yamamoto L, Rodrigues JC, Kanunfre KA, Okay TS. HLA-DQA1/B1 alleles as putative susceptibility markers in congenital toxoplasmosis. Virulence. 2016;7(4):456-64.

14. Neu N, Duchon J, Zachariah P. TORCH infections. Clin Perinatol. 2015 Mar;42(1):77-103.

15. Maldonado YA, Nizet V, Klein JO, Remington, JS, Wilson CB. Current Concepts of Infections of the Fetus and Newborn Infant. In: Christopher B. Wilson, Victor Nizet, Yvonne A. Maldonado, Jack S. Remington, Jerome O. Klein, editors. Remington and Klein's Infectious Diseases of the Fetus and Newborn Infant. Philadelphia: Elsevier Saunders. 8th ed. 2016. p.3-23

16. Miller JL., Harman C, Weiner C, Baschat AA. Perinatal outcomes after second trimester detection of amniotic fluid viral genome in asymptomatic patients. J Perinat Med. 2009;37: 140-3.

17. Pomares C, Montoya JG. Laboratory Diagnosis of Congenital Toxoplasmosis. J Clin Microbiol. 2016 Oct;54(10):2448-54.

18. Silasi M, Cardenas I, Kwon JY, Racicot K, Aldo P, Mor G. Viral infections during pregnancy. Am J Reprod Immunol. 2015 Mar;73(3):199-213.

19. Lazar M, Perelygina L, Martines R, Greer P, Paddock CD, Peltecu G. et al. Immunolocalization and Distribution of Rubella Antigen in Fatal Congenital Rubella Syndrome. EBioMedicine. 2015 Nov;27;3:86-92. 
20. Tabata T, Petitt M, Fang-Hoover J, Zydek M, Pereira L. Persistent Cytomegalovirus Infection in Amniotic Membranes of the Human Placenta. Am J Pathol. 2016 Nov;186(11):2970-86.

21. Coyne CB, Lazear HM. Zika virus - reigniting the TORCH. Nat Rev Microbiol. 2016 Nov;14(11):707-15.

22. Miura CS, Miura E, Mombach AB, Chesky M The prevalence of congenital cytomegalovirus infection in newborn infants at an intensive care unit in a public hospital..J Pediat. 2006;82(1),46-50.

23. Goegebuer T, Van Meensel B, Beuselinck K, Cossey V, Van Ranst M, Hanssens $\mathrm{M}$, et al. Clinical predictive value of real-time PCR quantification of human cytomegalovirus DNA in amniotic fluid samples. J Clin Microbiol. 2009; 47(3):6605 .

24. Ross SA, Novak Z, Fowler KB, Arora N, Britt WJ, Boppana SB. Cytomegalovirus blood viral load and hearing loss in young children with congenital infection. Pediatr Infect Dis J. 2009 Jul;28(7):588-92.

25. Tafreshi NK, Sadeghizadeh M, Amini-Bavil-Olyaee S, Ahadi AM, Jahanzad I, Roostaee MH. Development of a multiplex nested consensus PCR for detection and identification of major human herpesviruses in CNS infections. J Clin Virol. 2005 Apr;32(4):318-24.

26. Juul-Dam N, Townsend J, Courchesne E. Prenatal, perinatal, and neonatal factors in autism, pervasive developmental disorder-not otherwise specified, and the general population. Pediatrics. 2001 Apr;107(4):E63.

27. Dubey JP, Lago EG, Gennari SM, Su C, Jones JL. Toxoplasmosis in humans and animals in Brazil: high prevalence, high burden of disease, and epidemiology. Parasitology. 2012 Sep;139(11);1375-424.

28. Hohlfeld P, Daffos F, Costa JM, Thulliez P, Forestier F, Vidaud M. Prenatal diagnosis of congenital toxoplasmosis with a Polymerase-Chain-Reaction test on amniotic fluid. N Engl J Med. 1994;15:695-9.

29. Montoya JG, Remington JS. Management of Toxoplasma gondii infection during pregnancy. Clin Pract 2008;47: 554-66. 
30. Konstantinidou AE, Syridou G, Spanakis N, Tsakris A, Agrogiannis G, Patsouris E. Association of hypospadias and cardiac defect in a Parvovirus B19-infected stillborn: a causality relation? J Infect. 2007;54(1):e41-5.

31. Syridou G, Spanakis N, Konstantinidou A, Piperaki ET, Kafetzis D, Patsouris E, et al. Detection of cytomegalovirus, parvovirus B19 and herpes simplex viruses in cases of intrauterine fetal death: association with pathological findings. J Med Virol. 2008 Oct;80(10):1776-82.

32. Bonvicini F, Manaresi E, Gallinella G, Gentilomi GA, Musiani M, Zerbini M. Diagnosis of fetal parvovirus B19 infection: value of virological assays in fetal specimens. BJOG. 2009;116(6):813-7.

33. Towbin JA, Griffin LD, Martin AB, Nelson S, Siu B, Ayres NA, et al. Intrauterine adenoviral myocarditis presenting as nonimmune hydrops fetalis: diagnosis by polymerase chain reaction. Pediatr Infect Dis J. 1994 Feb;13(2):144-50.

34. Ranucci-Weiss D, Uerpairojkit B, Bowles N, Towbin JA, Chan L. Intrauterine adenoviral infection associated with fetal non-immune hydrops. Prenat Diagn. 1998 Feb;18(2):182-5.

35. Forsnes EV, Eggleston MK, Wax JR. Differential transmission of adenovirus in a twin pregnancy. Obstet Gynecol. 1998 May;91(5 Pt 2):817-8.

36. Oyer CE, Ongcapin EH, Ni J, Bowles NE, Towbin JA. Fatal intrauterine adenoviral endomyocarditis with aortic and pulmonary valve stenosis: diagnosis by polymerase chain reaction. Hum Pathol. 2000 Nov;31(11):1433-5.

37. Baschat AA, Towbin J, Bowles NE, Harman CR, Weiner CP. Is adenovirus a fetal pathogen? Am J Obstet Gynecol. 2003 Sep;189(3):758-63.

38. Puerari D, Camargo C, Gratura S, Watanabe ASA, Granato C, Bellei NCJ Aplicacão de teste molecular para deteccão de adenovírus em pacientes pediátricos distintos. Rev Paul Pediatr. 2015;33(2):136-41.

39. McLean LK, Chehab FF, Goldberg JD. Detection of viral deoxyribonucleic acid in the amniotic fluid of low-risk pregnancies by polymerase chain reaction. Am J Obstet Gynecol.1995 Oct;173(4):1282-6. 
40. Van den Veyver IB, Ni J, Bowles N, Carpenter RJ Jr, Weiner CP, Yankowitz J, et al. Detection of intrauterine viral infection using the polymerase chain reaction. Mol Genet Metab. 1998 Feb;63(2):85-95.

41. Baschat AA, Towbin J, Bowles NE, Harman CR, Weiner CP. Prevalence of viral DNA in amniotic fluid of low-risk pregnancies in the second trimester. J Matern Fetal Neonatal Med. 2003 Jun;13(6):381-4.

42. Reddy UM, Baschat AA, Zlatnik MG, Towbin JA, Harman CR, Weiner CP. Detection of viral deoxyribonucleic acid in amniotic fluid: association with fetal malformation and pregnancy abnormalities. Fetal Diagn Ther. 2005;20(3):203-7.

43. Fritsch A, Müller AL, Sanseverino MT, Kessler RG, Barrios PM, Patusco LM, et al. Nonimmune hydrops fetalis: two decades of experience in a university hospital. Rev Bras Ginecol Obstet. 2012 Jul;34(7):310-5.

44. McIver CJ, Jacques CF, Chow SS, Munro SC, Scott GM, Roberts JA et al. Development of multiplex PCRs for detection of common viral pathogens and agents of congenital infections. J Clin Microbiol. 2005;43:5102-10.

45. Adams LL, Gungor S, Turan S, Kopelman JN, Harman CR, Baschat AA. When are amniotic fluid viral PCR studies indicated in prenatal diagnosis? Prenat Diagn. 2012 Jan;32(1):88-93

46. Leruez-Ville M, Ville Y. Optimum treatment of congenital cytomegalovirus infection. Expert Rev Anti Infect Ther. 2016;14(5):479-88.

47. Hughes BL, Gyamfi-Bannerman C. Diagnosis and antenatal management of congenital cytomegalovirus infection. Am J Obstet Gynecol. 2016 Jun;214(6):B5B11.

48. Mets MB, Holfels E, Boyer KM, Swisher CN, Roizen N, Stein L, et al. Eye manifestations of congenital toxoplasmosis. Am J Ophthalmol. 1997;123:1-16.

49. Nakajima-Iijima S, Hamada H, Reddy P, Kakunaga T. Molecular structure of the human cytoplasmic beta-actin gene: interspecies homology of sequences in the introns. Proc Natl Acad Sci U S A. 1985 Sep;82(18):6133-7. 
50. Coiras MT, Aguilar JC, Garcia ML, Casas I, Perez-Brena P. Simultaneous detection of fourteen respiratory viroses in clinical specimens by two multiplex reverse transcription nested-PCR assays. J Med Virol. 2004;72:484-95.

51. Templeton KE, Scheltinga SA, Beersma MF, Kroes AC, Claas EC. Rapid and sensitive method using multiplex-real time PCR for diagnosis of infections by influenza $A$ and influenza $B$ viruses, respiratory syncytial virus, and parainfluenza viruses 1, 2, 3 and 4. J Clin Microbiol 2004;42: 1564-9.

52. Beuret C. Simultaneous detection of enteric viruses by multiplex-real time RTPCR. J Virol Methods. 2004;115: 1-8.

53. Chichili GR, Athmanathan S, Farhatullah S, Gangopadthyay N, Jalali S, Pasricha $\mathrm{G}$, et al. Multiplex polymerase chain reaction for the detection of herpes simplex virus, varicella-zoster virus and cytomegalovirus in ocular specimens. Curr Eye Res. 2003;27:85-90.

54. Nopponpunth V, Changrad S, Rakyuu A, Nertsawange J, Chansupit W, Poovorawan Y. Design of degenerate primers for multiplex nested-PCR detection of human lymphotropic herpesvirus. Southeast Asian J Trop Med Public Health. 2003;34: 120-5.

55. Calvario A, Bozzi A, Scarasciutti M, Ventola C, Seccia R, Stomati D, et al. Herpes consensus PCR test: a useful diagnostic approach to test the screening of viral diseases of the central nervous system. J Clin Virol. 2002;25(Suppl. 1): S71-7.

56. Mackay IM, Gardam T, Arden KE, Whiley DM, Crisante E, Sloots TP. Codetection and discrimination of six human herpesviruses by multiplex PCR-ELAHA. J Clin Virol. 2003;28:291-302.

57. Tarrago D, Quereda C, Tenorio A. Different cytomegalovirus glycoprotein B genotype distribution in sérum and cerebrospinal fluid specimens determined by a novel multiplex nested PCR. J Clin Microbiol. 2003;41: 2872-7.

58. Dard C, Fricker-Hidalgo H, Brenier-Pinchart MP, Pelloux H. Relevance of and New Developments in Serology for Toxoplasmosis. Trends Parasitol. 2016 Jun;32(6):492-506. 
59. Rolfs A, Schuller I, Finckh U, Weber-Rolfs I: In PCR: clinical diagnostics and research. Berlin: Springer; 1992:61-7.

60. Donner C, Liesnard C, Brancart F, Rodesch F. Accuracy of amniotic fluid testing before 21 weeks gestation in prenatal diagnosis of congenital cytomegalovirus infection. Prenatal diagnosis 1994;14(11):1055-9.

61. Kilic N, Yazici Z. A case of holoprosencephaly and cebocephaly associated to torch infection. Int J Pediatr Otorhinolaryngol 2005;69:275-8.

62. Atreya CD, Mohan KV, Kulkarni S.Rubella virus and birth defects: molecular insights into the viral teratogenesis at the cellular level. Birth Defects Res A Clin Mol Teratol. 2004 Jul;70(7):431-7.

63. De Catte L, De Keersmaeker B, Claus F Prenatal neurologic anomalies: sonographic diagnosis and treatment. Paediatr Drugs. 2012 Jun 1;14(3):143-55

64. Goodrum F. Human Cytomegalovirus Latency: Approaching the Gordian Knot. Annu Rev Virol. 2016 Sep 29;3(1):333-57.

65. Buehler J, Zeltzer S, Reitsma J, Petrucelli A, Umashankar M, Rak M, et al. Opposing Regulation of the EGF Receptor: A Molecular Switch Controlling Cytomegalovirus Latency and Replication. PLOS Pathog. 2016 May 24;12(5):e1005655

66. Piedade D, Azevedo-Pereira JM. The Role of microRNAs in the Pathogenesis of Herpesvirus Infection. Viruses. 2016 Jun 2;8(6): E156.

67. Phan AT, Fernandez SG, Somberg JJ, Keck KM, Miranda JL. Epstein-Barr virus latency type and spontaneous reactivation predict lytic induction levels. Biochem Biophys Res Commun. 2016 May 20;474(1):71-5.

68. Markus A, Lebenthal-Loinger I, Yang IH, Kinchington PR, Goldstein RS. An in vitro model of latency and reactivation of varicella zoster virus in human stem cellderived neurons. Pathog. 2015 Jun 4;11(6):e1004885. 
69. Kennedy PG, Rovnak J, Badani H, Cohrs RJ. A comparison of herpes simplex virus type 1 and varicella-zoster virus latency and reactivation. J Gen Virol. 2015 Jul;96(Pt 7):1581-602.

70. Ouedraogo AR, Kabre M, Bisseye C, Zohoncon TM, Asshi M, Soubeiga ST. Molecular tests in diagnosis of Cytomegalovirus (CMV), human herpesvirus 6 (HHV6) and Epstein-Barr virus (EBV) using real-time PCR in HIV positive and HIVnegative pregnant women in Ouagadougou, Burkina Faso. Pan Afr Med J. 2016 Jul $12 ; 24: 223$.

71. Rasti S, Ghasemi FS, Abdoli A, Piroozmand A, Mousavi SG, Fakhrie-Kashan Z. ToRCH "co-infections" are associated with increased risk of abortion in pregnant women. Congenit Anom (Kyoto). 2016 Mar;56(2):73-8.

72. Wagner J, Dzijan S, Pavan-Jukić D, Wagner J, Lauc G. Analysis of multiple loci can increase reliability of detection of fetal Y-chromosome DNA in maternal plasma. Prenat Diagn. 2008 May;28(5):412-6.

73. Yang YH, Yang ES, Kwon JY, Kim IK, Park YW. Prenatal diagnosis of trisomy 21 with fetal cells in maternal blood using comparative genomic hybridization. Fetal Diagn Ther. 2006;21(1):125-33.

74. Kølvraa S, Singh R, Normand EA, Qdaisat S, van den Veyver IB, Jackson L et al. Genome-wide copy number analysis on DNA from_fetal_cells_isolated from the blood of pregnant women. Prenat Diagn. In press 2016.

75. Torpey K, Mandala J, Kasonde P, Bryan-Mofya G, Bweupe M, Mukundu J. Analysis of HIV early infant diagnosis data to estimate rates of perinatal HIV transmission in Zambia. PLoS One. 2012;7(8):e42859.

76. Chang J, Tarasova T, Shanmugam V, Azarskova M, Nguyen S, Hurlston M et al. Performance of an Early Infant Diagnostic Test, AmpliSens DNA-HIV-FRT, Using Dried Blood Spots Collected from Children Born to Human Immunodeficiency VirusInfected Mothers in Ukraine. J Clin Microbiol. 2015 Dec;53(12):3853-8.

77. Lissauer D, Goodyear O, Khanum R, Moss PA, Kilby MD. Profile of maternal CD4 T-cell effector function during normal pregnancy and in women with history of recurrent miscarriage. Clin Sci (Lond). 2014 Mar;126(5):347-54 
78. Maymon R, Weinraub Z, Herman A. Pregnancy outcome of euploid fetuses with increased nuchal translucency: how bad is the news? J Perinat Med. 2005;33(3):1918.

79. Yamakawa R, Yamashita Y, Yano, A Morita, Kato H. Congenital toxoplasmosis complicated by central diabetes insipidus in an infant with Down syndrome. Brain Dev. 1996; 18:75-7

80. Il'inskikh NN, Il'inskikh IN, Shustrov AK Role of Toxoplasma gondii in human and animal chromosomal pathology. Parazitologiia. 1979 May-Jun;13(3):235-40.

81. Laziuk GI, Nedz'ved' MK, Kravtsova GI. Combination of Patau's syndrome (trisomy 13) with congenital toxoplasmosis Pediatr Akus Ginekol. 1978 JanFeb;(1):58

82. Von Graefes A Arch Toxoplasmosis as a probable mutagenic factor Klin Exp Ophthalmol.1966 Aug 15;170(3):223-34.

83. Morava E, Varga L, Czakó M, Decsi T. Materna ltoxoplasma infection and mosaic trisomy 8 syndrome. Orv Hetil. 2002 Mar 17;143(11):563-5.

84. Yolken RH, Bachmann S, Rouslanova I Antibodies to Toxoplasma gondii in individuals with first-episode schizophrenia. Clin Infect Dis. 2001; 32:842-4.

85. Goetzl L. Adverse pregnancy outcomes after abnormal first-trimester screening for aneuploidy. Clin Lab Med. 2010 Sep;30(3):613-28. 
Ao

Departamento de Obstetrícia e Ginecologia

A Comissão de Ética para Análise de Projetos de Pesquisa-CAPPesq da Diretoria Clínica do Hospítal das Clínicas da Faculdade de Medicina da Universidade de São Paulo, APrOvOU na sessão datada de 09.11.11 a execução do subprojeto intitulado “DESENVOLVIMENTO DE UM MULTIPLEX-NESTED-PCR E UM MULTIPLEX-NESTEDRT-PCR PARA A DETECÇÃO dOS PRINCIPAIS PAT́́GENOS CAUSADORES DE INFECCŌES CONGENITAS", que será tese de doutonado da aluna UDIA YAMAMOTO, tendo como orlentadora a PROFa. DRa. THEMMA SUEYY OKAY.

O referido projeto faz parte do Protocolo de Pesquisa $n^{\circ}$ 0116/10, intitulado "Desenvolvimento de métodos moleculares para a defecçōo dos paibgenos maits comuns em infecçōes congêniltas no Serviço de Obstetricia do Hosplital das Clínicas da Faculdade de Medicina da Universidade de Sāo Paulo", aprovado por esta CAPPesq em 26.05.10.

CAPPesq, 11 de Novembrode 2011.

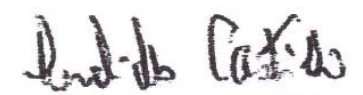

PROF. DR. EUCUDES AYRES DE CASTILHO Coordenador Comissāo de Elitica pora Anćlitse de Projetos de Pesquisa - CAPPesq 
ANEXO 2 - APROVAÇÃO DA COMISSÃO DE ÉTICA E PESQUISA

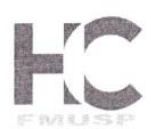

\author{
Hospital das Clínicas da FMUSP \\ Comissão de Ética para Análise de Projetos de Pesquisa \\ CAPPesq
}

No Protocolo: $0116 / 10$

Título: DESENVOLVIMENTO DE MÉTODOS MOLECULARES PARA A DETECÇÃO DOS

PATÓGENOS MAIS COMUNS EM INFECÇÕES CONGÊNITAS NO SERVIÇO DE

OBSTETRÍCIA DO HOSPITAL DAS CLÍNICAS DA FACULDADE DE MEDICINA DA

UNIVERSIDADE DE SÃO PAULO.

Pesquisador Responsável: Dra Joelma Queiroz Andrade, Dra Thelma Suely Okay

Pesquisador Executante: Vagner Oliveira Carvalho, Lilia Targa, Paulo Tadashi

Shimokawa, Antonio Walter Ferreira, Antonio Gomes de Amorim Filho, Adolfo Liao,

Marcelo Zugaib

Finalidade Acadêmica: Mestrado

Departamento: OBSTETRÍCIA E GINECOLOGIA

A Comissão de Ética para Análise de Projetos de Pesquisa CAPPesq da Diretoria Clínica do Hospital das Clínicas da Faculdade de Medicina da Universidade de São Paulo, APROVOU / TOMOU CIÊNCIA na sessão datada de 09/11/2011, do(s) documento(s) abaixo mencionado(s):

- Carta datada de 19/09/2011 - Relatório parcial;

- Troca de pesquisador executante para Lidia Yamamoto;

- Alteração de título para Desenvolvimento de um multiplex-PCR e um multiplex-nested-RT-PCR para a detecção dos princípios patógenos de infecções congênitas.

A CAPPesq em obediência à Resolução CNS 196/96, solicita ao pesquisador (a) s elaboração de relatório parcial e final.

No caso de relatório parcial é necessário informar o tempo previsto para a conclusão do protocolo e breve resumo dos resultados obtidos.

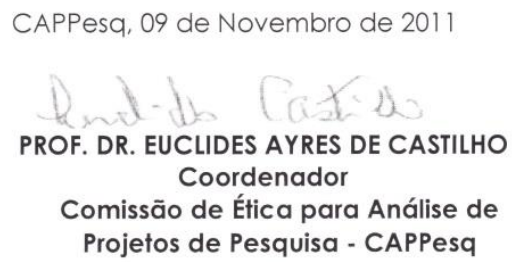

